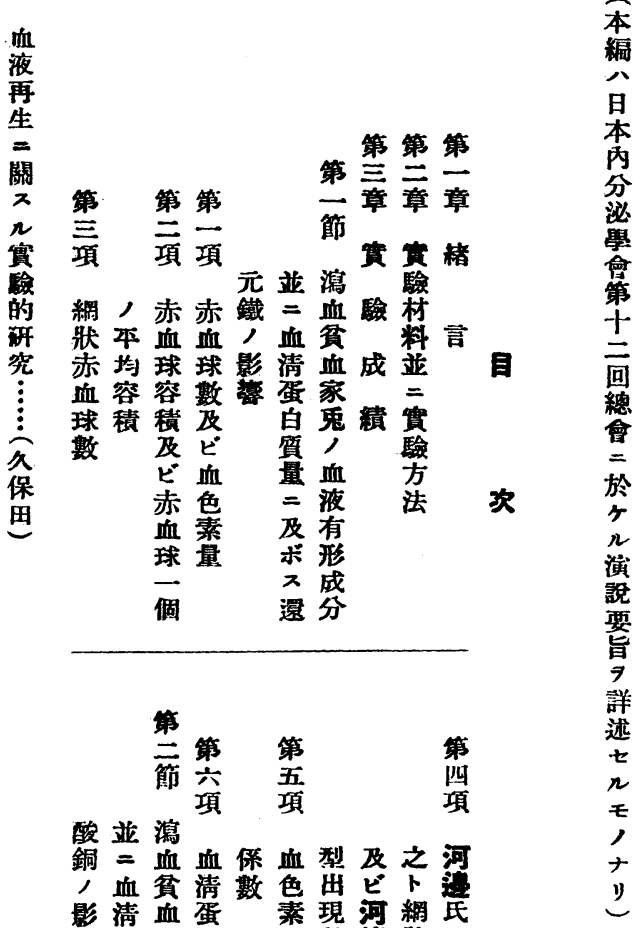

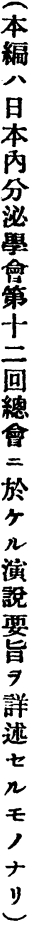

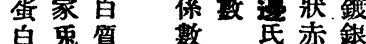

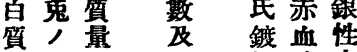

量血 ビ 銀球赤

=液 血 性數血

及有色赤球

一 形素血人數

二 $\quad$ 成 漂球關並

朆 國

學 大

\pm 學

第

IIII.

縓

液

再

及瀉生

ボ血

不貧二

還 血

元 家

關

鐵 兔

或,

八血

硫 液

大

酸有實

銅 形

, 成 驗

影分

響及 的

久䁷衄 究

㩐

蛋

保队

科

田室

白

質

量

勉 


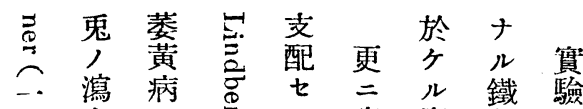

九血二、咢 ラ 臨赛劑的

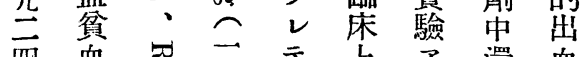

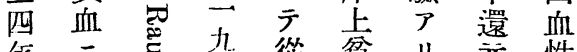

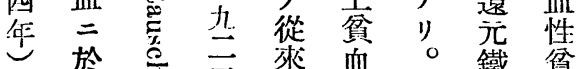

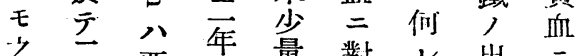

忘價 惡 性

替鐵貧 1 鐵 亏 䢬性木

シナ血 ンキ 鐵元貧

炭二フ 使 劑鐵 血鐵

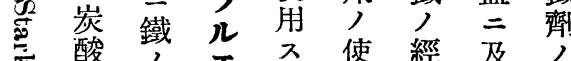

离酸人 エ

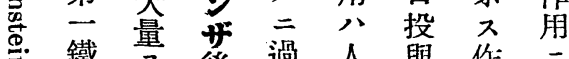

导鐵 7 量 徭 過 與作二

$\frown \cong$ 使光代體分用就

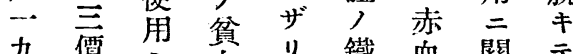

九偠 シ 血り鐵血關 テ

二鐵、、 三 需球 シ 諸

六ナ 何二モ、要 數 テ 芜

年儿上水レ量韭八了

- 酸 其 方

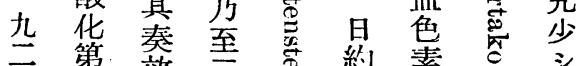

元第效 至离 約 素

年 鐵 著瓦 こ

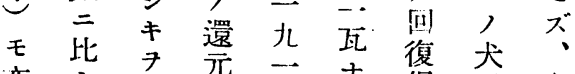

亦卞認鐵八公堡、今

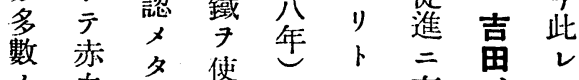

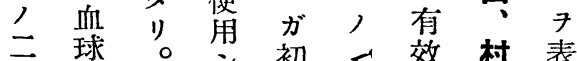

價球。初公效 村表

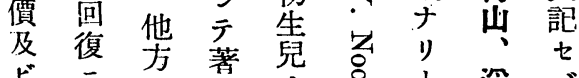

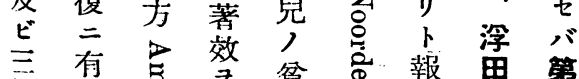

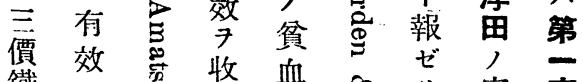

鐵效展收 血

絈り

藥卜九次量區尔如

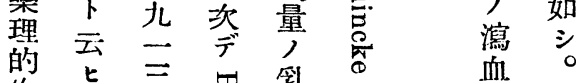

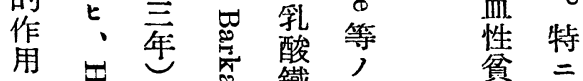

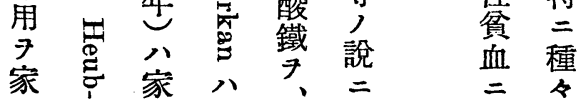

第

第第 第第 關

四等 $\stackrel{\text { 三 }}{二}$ 第

項項 項項 實

及之河網 八赫赤的

ビ卜邉狀平血血 研

河網氏赤均球球究

䟂狀鍍血容容數

氏赤銀球皘積及

鍍 血性 數

銀球赤

性 數 血

赤卜球

血關亚

各保 =

及 ビ

ビ 血

赤色

血素 田

春

咸

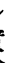

$\vdots$

久

保

球 量

個
血

再

第

四第

章節六第

䊅 項 愐

諭 總

並括血保血型

並清數色出

主 = 蛋 素現

要考白保數

交察質數

献量媼及 


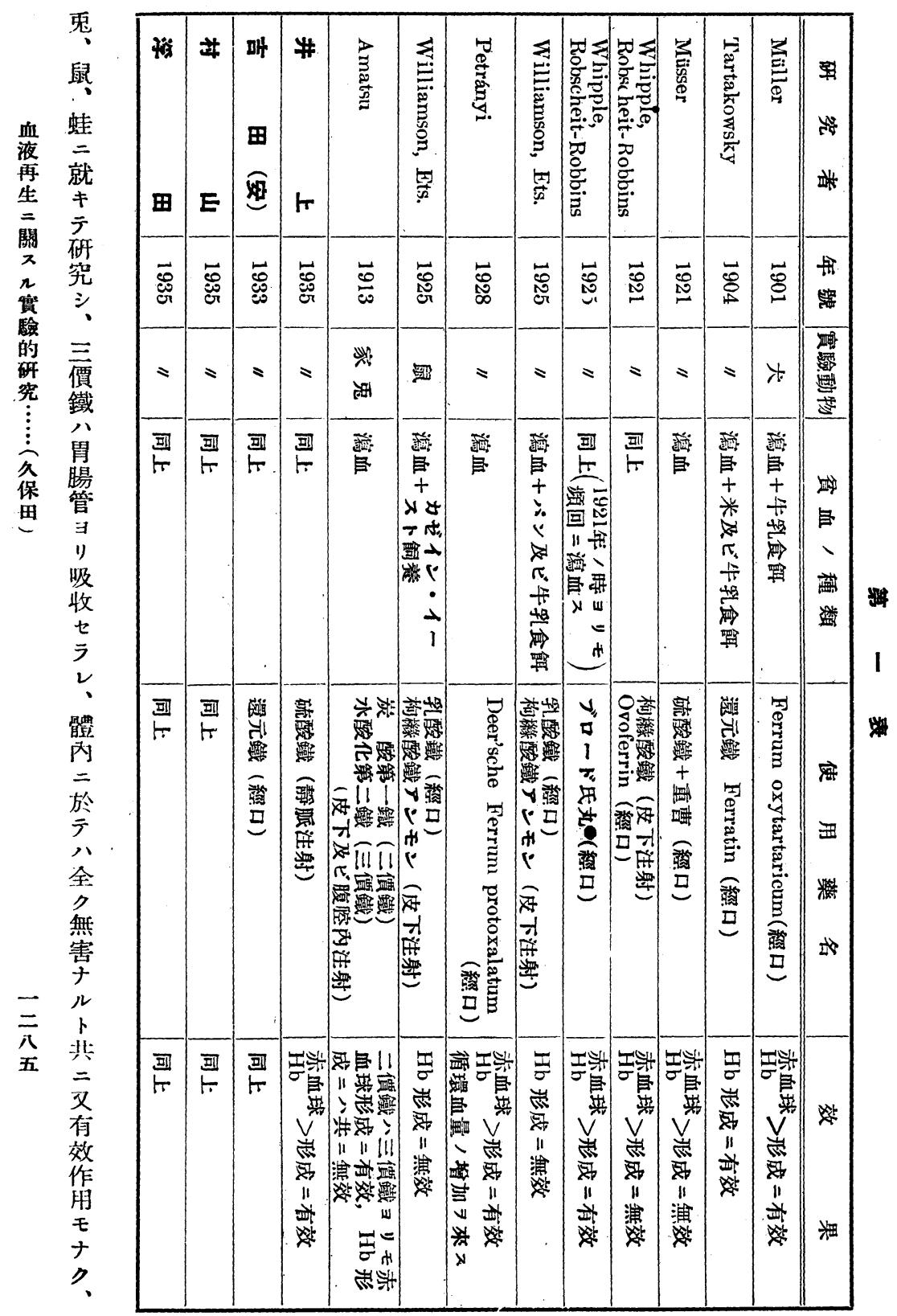




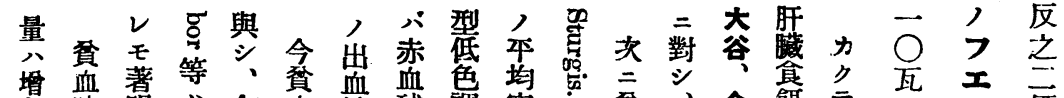

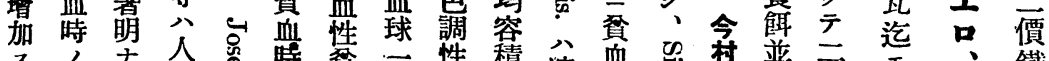

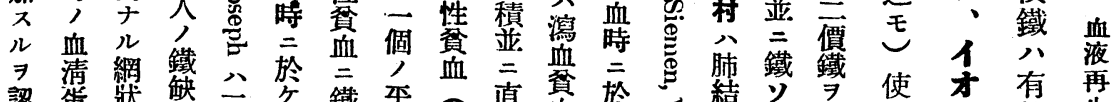

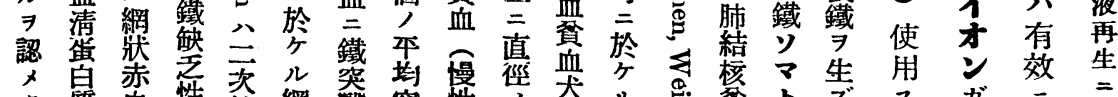

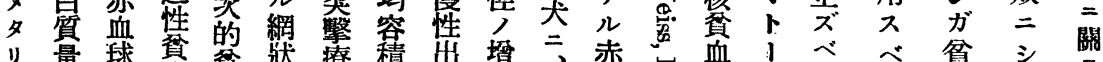

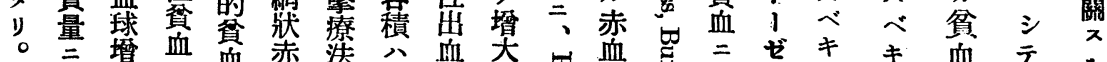

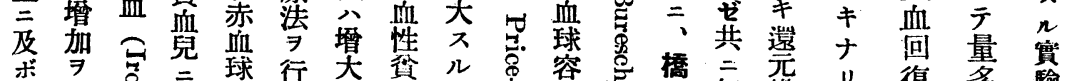

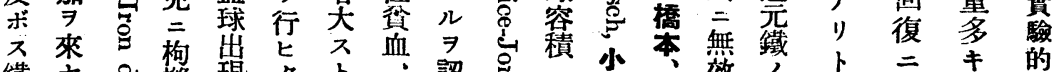

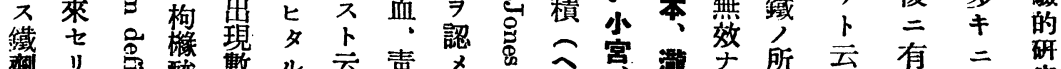

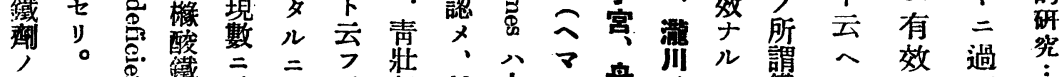

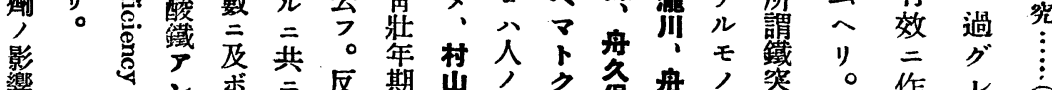

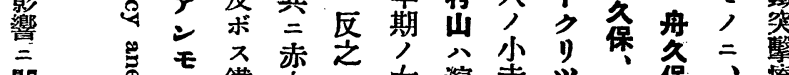

關 テ 投

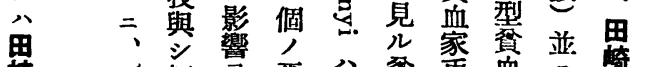

永 宮 少 田

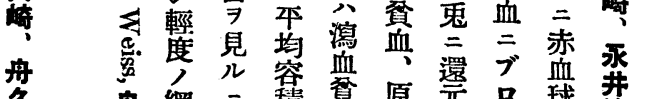

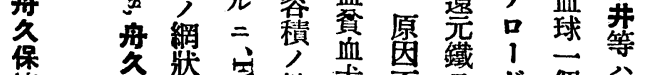

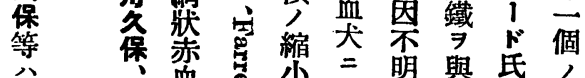

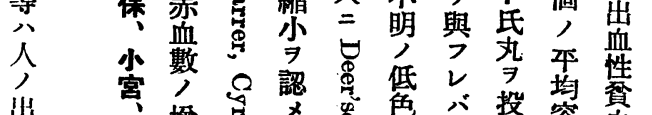

岀

血

奜

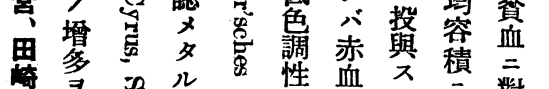

弄公種

苦蕡

守病畜

松出

坂 血 䳡

八性 筩

十寶七

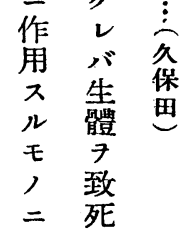

シ

テ シ

無公

症 而

二 $シ$

八 テ

豫 僈

$x \quad \overline{\mathrm{U}}$

旍 鐵

监

血

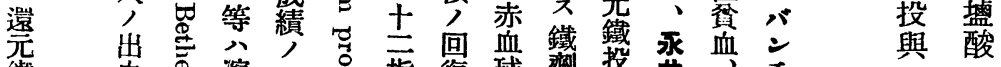

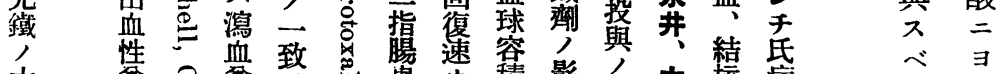

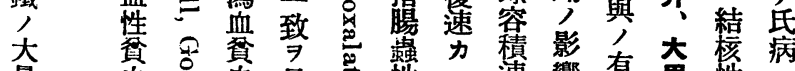

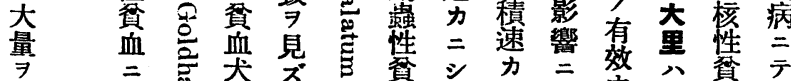

$\Rightarrow$ =

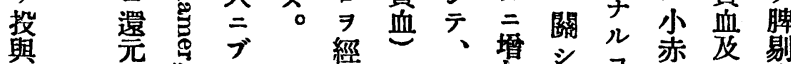

ス 鐵

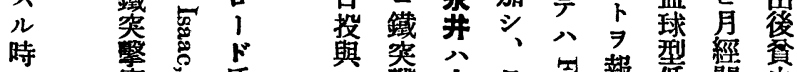

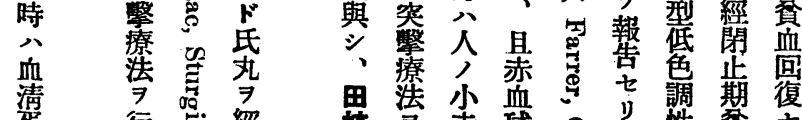

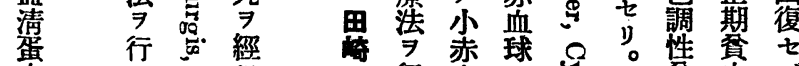

ク $\frac{\text { テ }}{\bar{\lambda}}$

又 盍

還 化

元 第

鐵 -

八鐵

大 =

量 變

化

日之 


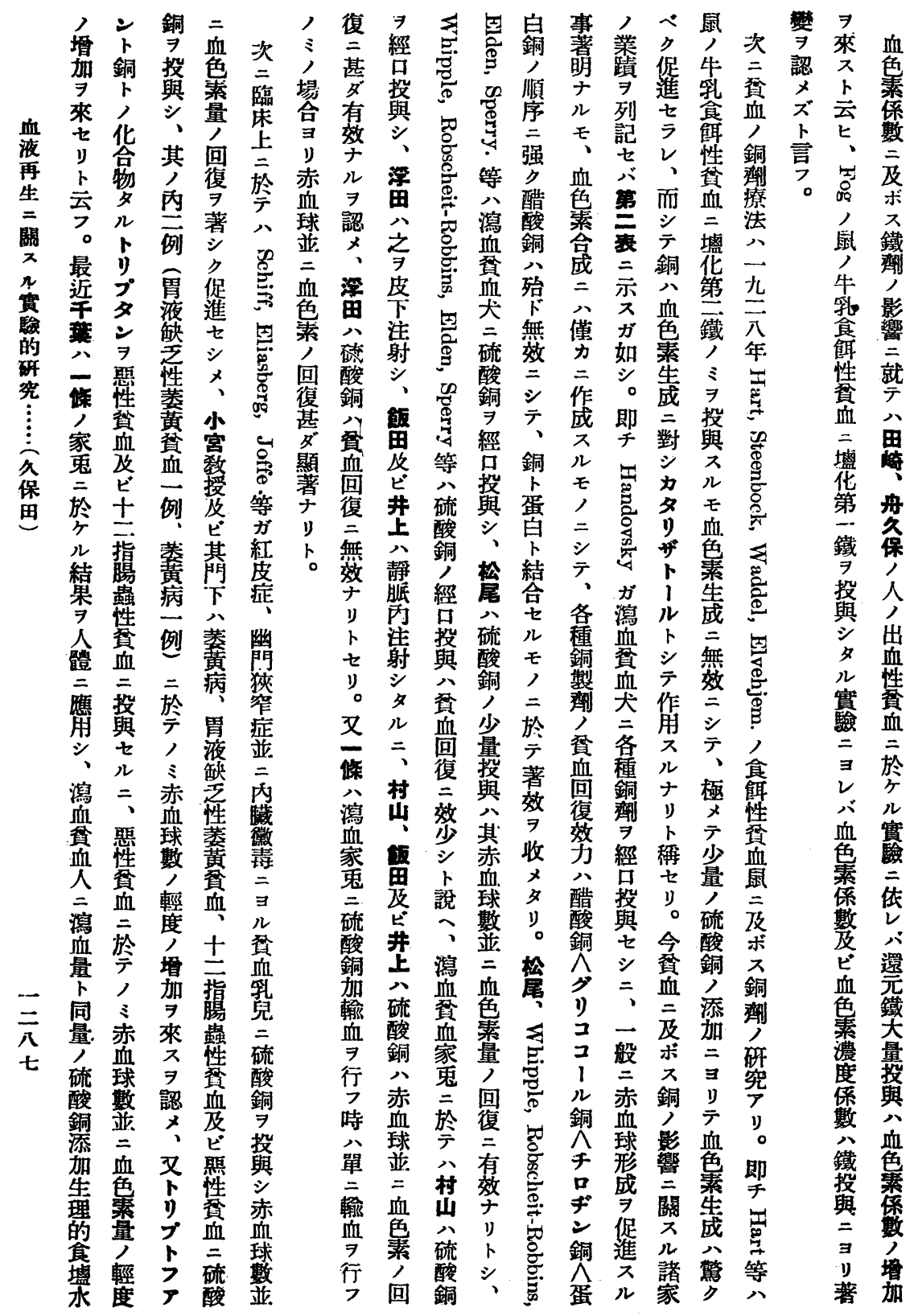




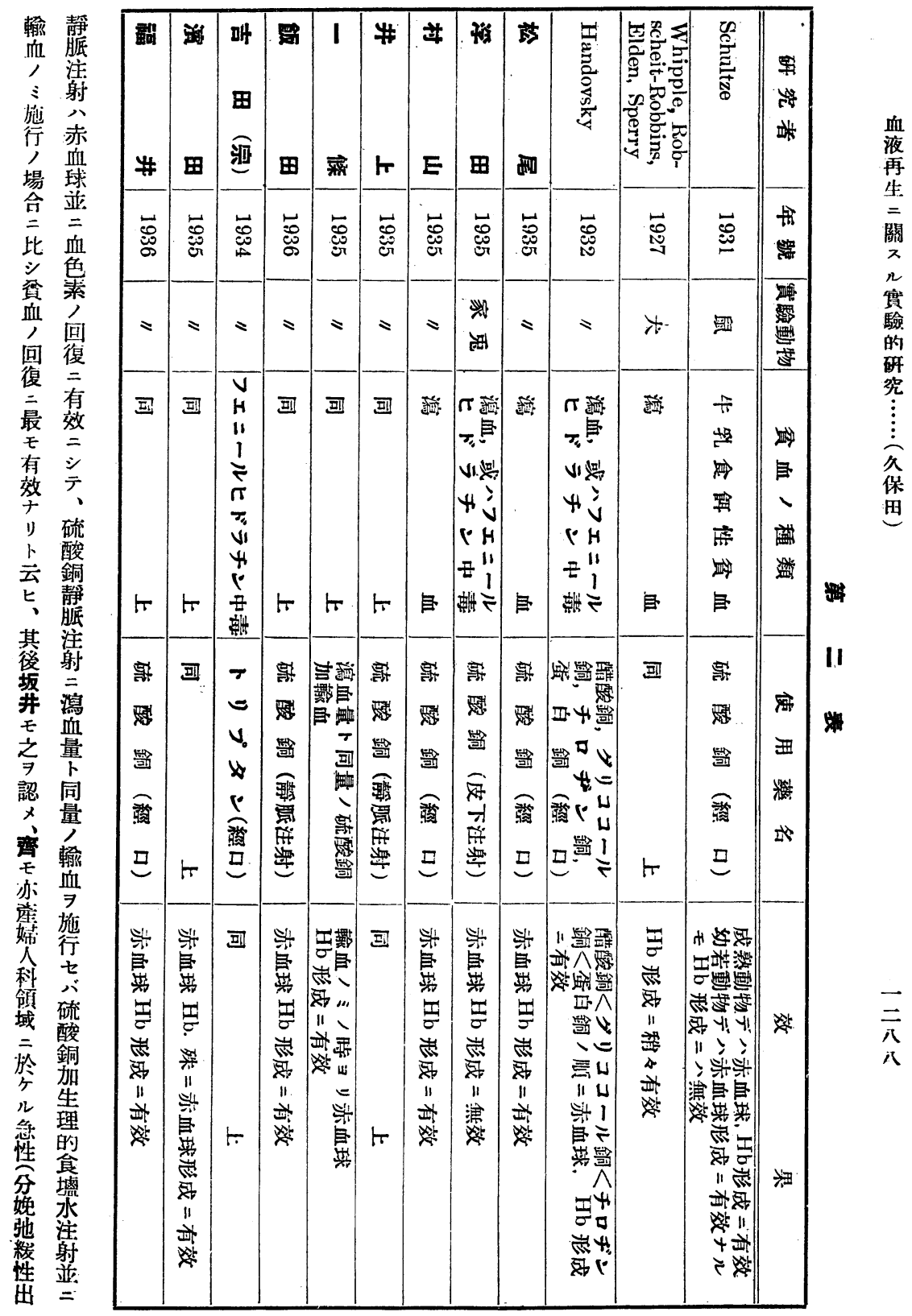




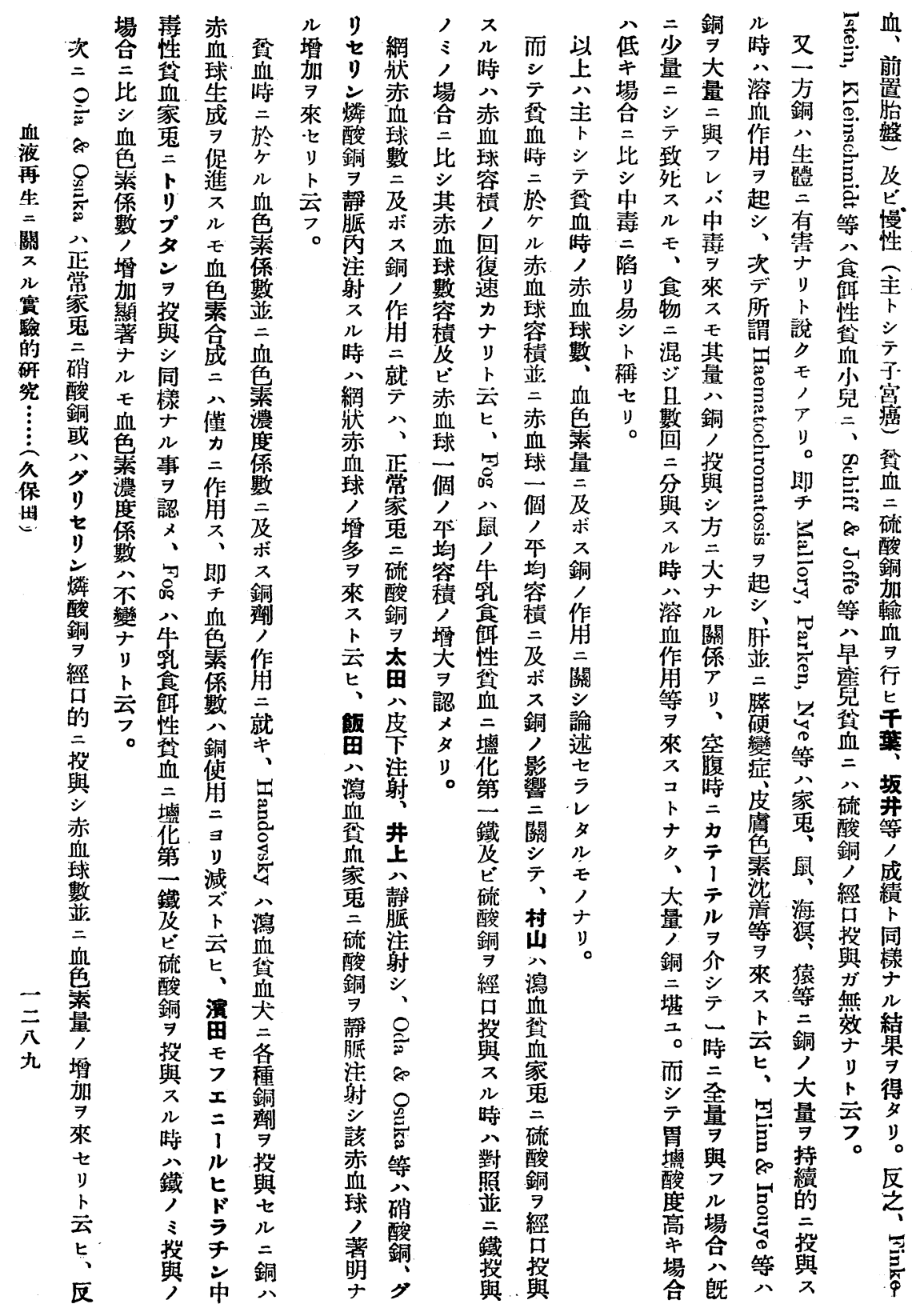


各 河 八 血 射 數 等 網 成氏 タ、略血構八影數了響上年 分 鍍 興 几 安 球 造 既 響 影三述上

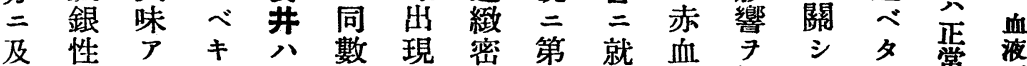

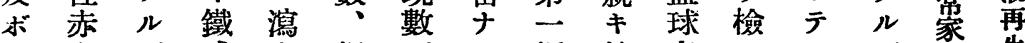
ス血可或血相 ガ 編綜容 七八力菟生 鐵球 $キ$ 分平瀉 $\mathrm{A}$ 二合積 ル多如並閏 或數 7 銅 血 行 血型於的、菲 ク ク

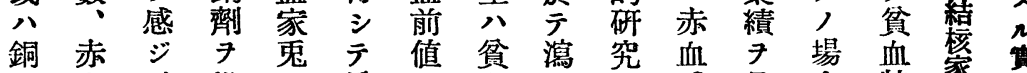
人血、投二增二血血 7 球見合特家驗 作球 瀉 與 ソ 減復回貧試一ル有二鬼的 用容血 シ ラ 歸復血 $i$ 個二效出硫

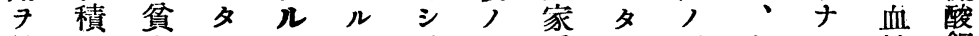
綜: 血ルツモ・初鬼ル平主リ性銅 合赤家場 $ン$ 且期ノ 的血鬼合 $ナ$ 鍍二貧, 容シ 的血 鬼合 皮 查個元氏 注 發赤造 復聞血色稀 汷 シ, 鐵 鍍射表血粗開朱色素二還夕 、本或銀 シ 七球始名素量無元ル

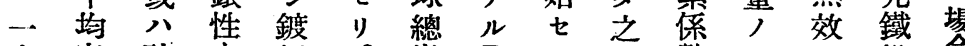
定容硫赤銀。出 B ン 數i投合 成積 酸 血 性 而 現 型 績 血 $尹$ 血

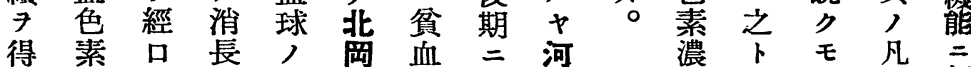

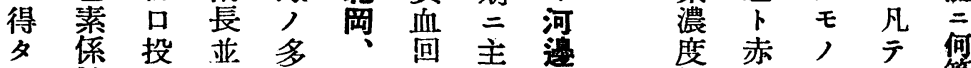

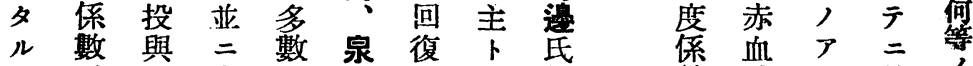
7、文之出八, 少鍍數球り於

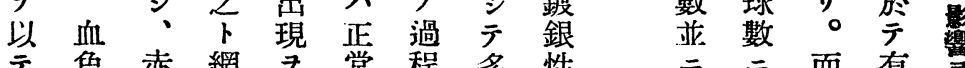

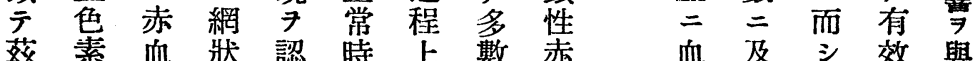

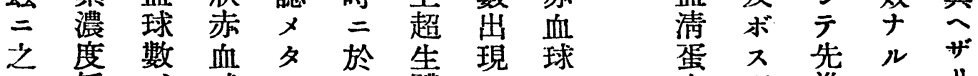
牦、球り々體シ人 報數 血數。色、增 告亚色卜 然鼠素貧 加 七二素, 二 二染血著 ン血量關バ硫色ノ明

卜清: 係瀉酸性全ナ

ス 蛋 網 如血銅 網 ク

。百狀何貧 狀问 䍃赤 7 血 頻赤復見 量 血研家宽自皮球 ル 就 血數 $ᄌ=$ 出時中 液、造注現此其

白影進 7 少

質響 諸認キ三三 量 7 蒙 七貧 $v$ 。 血ル 血 タ 液 二 二 各止及モ 種り、文、銅 分 網 鐵 濟 二狀 或 投 及 赤 八 與 

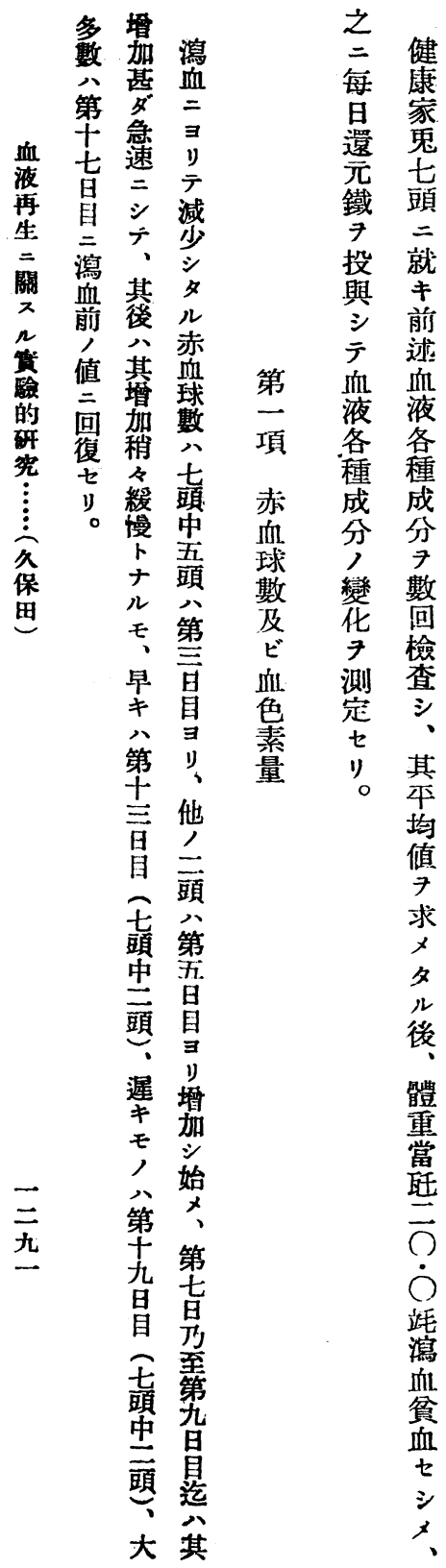

站、重而惯

體 糟還投物 六全鐵页血 正量 $O \neq$ 篷

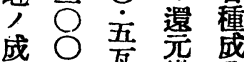

三 前

第血 血

液 液

項 各 各

種 種

成 成

血 分 分

, 7

數 變 數

化 回

子檢

血. 测 香

色定

及

术血

万畕 駱

薑血

完

鐵鬼

績

成鐵々溶 法

第

影血

花

有

1) 其

晟

八 $\exists$ 掖

旦覆

衣沓選

硫旦量它既

恶

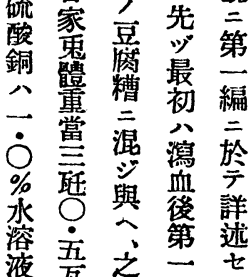

體

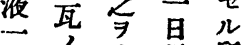

○還完自所

官筧全血全

㜪

二或鿖侅同

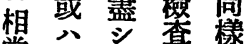

㴧

○多吉

。充儿探》。

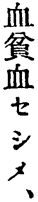

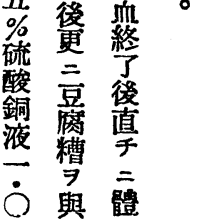




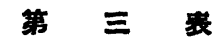

\begin{tabular}{|c|c|c|c|c|c|c|c|c|c|c|}
\hline \multirow{2}{*}{\begin{tabular}{l|} 
家 \\
鬼 \\
番 \\
㙱 \\
\end{tabular}} & \multirow{2}{*}{$\begin{array}{c}\text { 體 } \\
\text { 重 } \\
(\text { 互 }\end{array}$} & \multirow{2}{*}{$\begin{array}{c}\text { 晹 } \\
\text { 血 } \\
\text { 量 } \\
\text { (c.c.) }\end{array}$} & \multicolumn{2}{|c|}{ 渲 血 前 } & \multicolumn{2}{|c|}{ 鵍血後第一日目 } & \multicolumn{2}{|c|}{ 回 復 時 } & \multicolumn{2}{|c|}{$\begin{array}{l}\text { 回復=要 } \\
\text { 七之日數 }\end{array}$} \\
\hline & & & $\begin{array}{c}\text { 告血球數 } \\
\text { (禹) }\end{array}$ & $\begin{array}{c}\begin{array}{c}\text { 血色素量 } \\
(\%)\end{array} \\
\end{array}$ & $\begin{array}{c}\text { 告血球數 } \\
\text { (禹) }\end{array}$ & $\begin{array}{c}\text { 血色素量 } \\
(\%) \\
\end{array}$ & 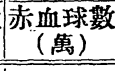 & $\begin{array}{c}\begin{array}{c}\text { 血色素量 } \\
(\%)\end{array} \\
\end{array}$ & 赤血球 & 血色素 \\
\hline 21 & 2670 & 52 & 646 & 98 & 439 & 71 & 668 & 98 & 17 & 15 \\
\hline 22 & 3080 & 62 & 561 & 94 & 336 & 55 & 581 & 94 & 19 & 15 \\
\hline 23 & 2940 & 60 & 593 & 96 & 345 & 51 & 616 & 96 & 17 & 17 \\
\hline 24 & 2870 & 57 & 609 & 92 & 395 & 52 & 625 & 94 & 13 & 15 \\
\hline 25 & 2950 & 58 & 600 & 91 & 322 & 50 & 605 & 91 & 19 & 21 \\
\hline 26 & 2840 & 56 & 667.5 & $10 ;$ & 393 & 61 & 690 & 103 & 17 & 17 \\
\hline 27 & 2985 & 60 & 578 & 92 & 372 & 51 & 640 & 91 & 13 & 11 \\
\hline 平 & 2905 & 57.9 & 607.8 & 95.1 & 371.7 & 55.9 & 632.1 & 95.3 & 16 & 16 \\
\hline
\end{tabular}

苐四表 赤血球容積 （\%)

\begin{tabular}{|c|c|c|c|c|}
\hline 家鬼番號 & 瀉血前 & 淮血 後 & 回復時 & \begin{tabular}{|l|}
$\mid$ 凹復二留 \\
七シ日數
\end{tabular} \\
\hline 21 & 43.0 & 28.1 & 45.0 & 7 \\
\hline 22 & 40.0 & 23.2 & 40.1 & 7 \\
\hline 25 & 38.1 & 21.0 & 38.0 & 7 \\
\hline 平均 & 40.4 & 24.1 & 41.0 & 7 \\
\hline
\end{tabular}

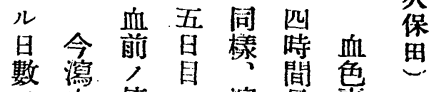

血吾闹四 齐 先 較 前

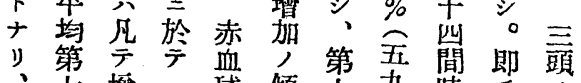

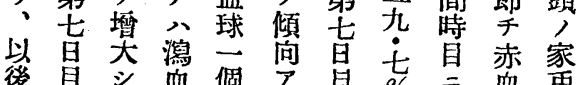

後目㴧個 $\mathrm{P}$ 目 \%三血鬼

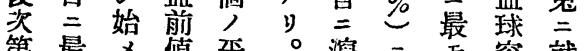

第最 、值平。瀉均減容就

隇値早此容

少手積

シ潟 八テ分

第 血 第 大三

十前吾美坆

艿值目共䳍

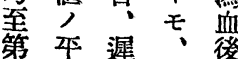

十均第

日 第白㞦

自艺自時

平倍目当算

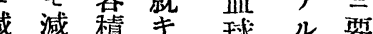

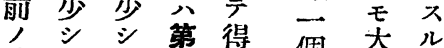

值、、西奨個大䚙日

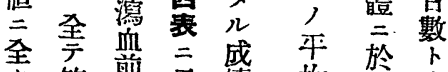

全第前示荗 均 於走

回笔分整容大血

复夏值方總

、前平均另、括

積 差 球

\% 數

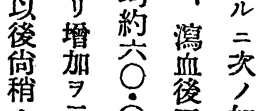

茨 覆 

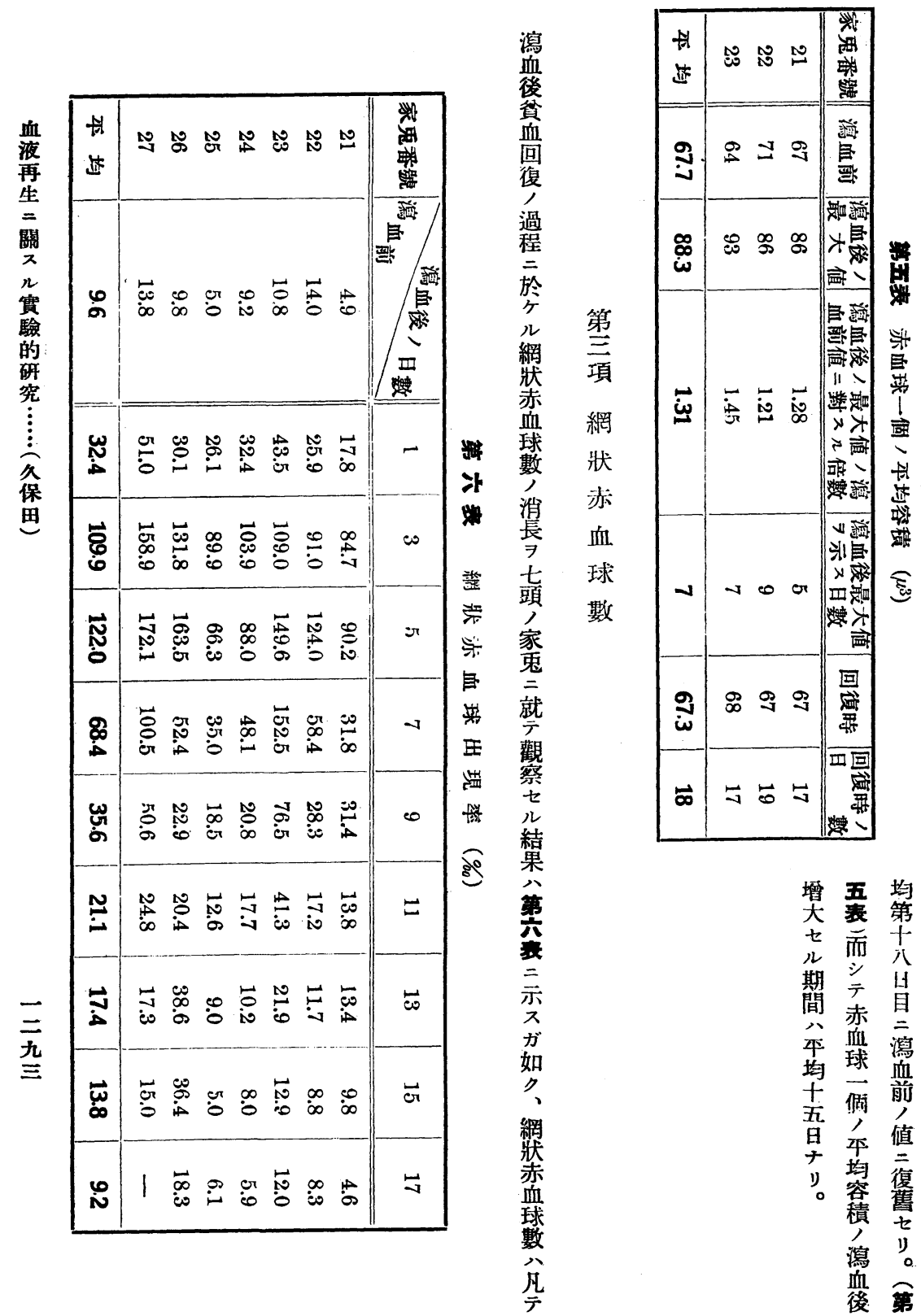


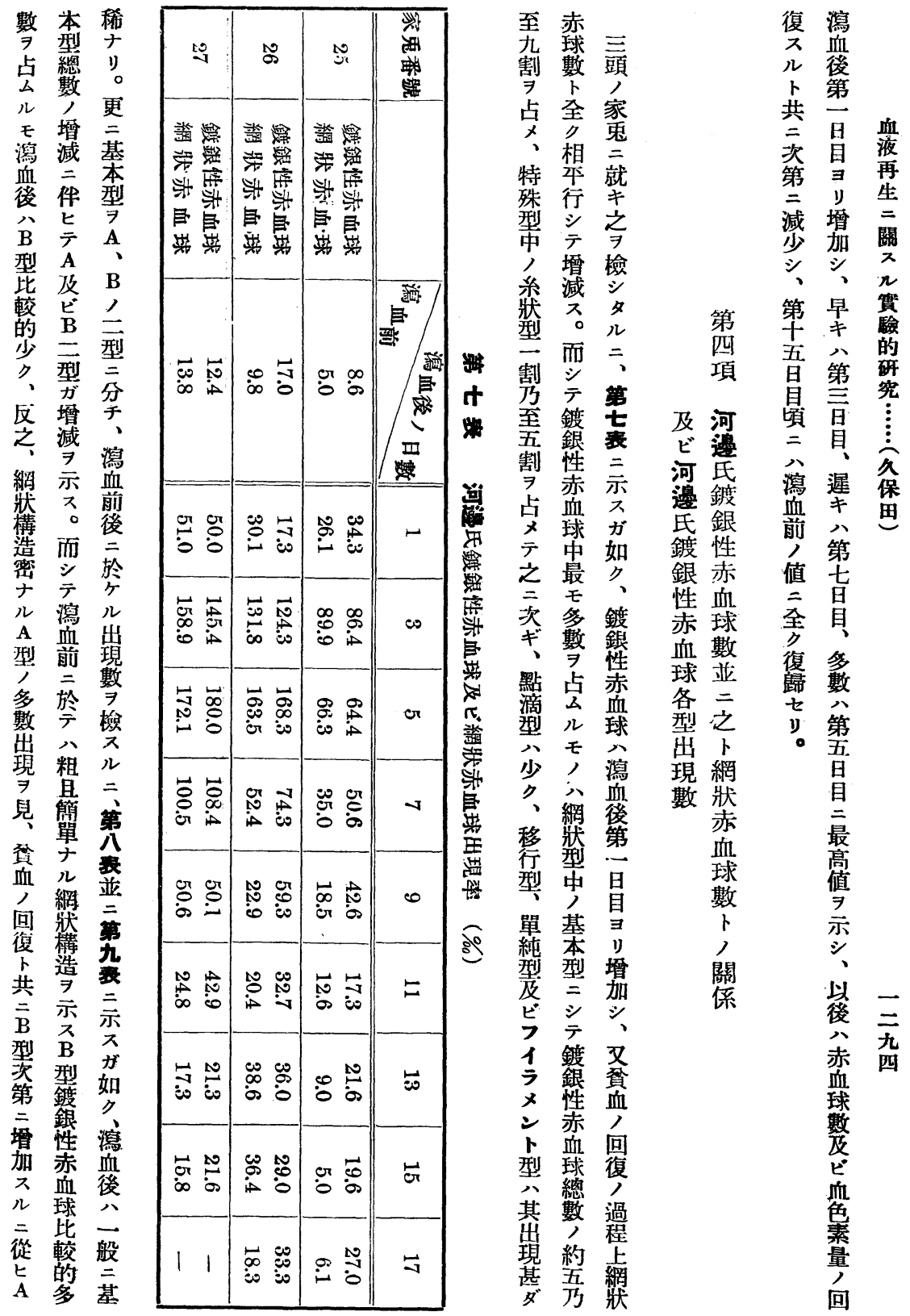


第八表 Nr. 25

\begin{tabular}{|c|c|c|c|c|c|c|c|c|}
\hline \multirow{2}{*}{ 月 日 } & \multirow{2}{*}{$\mid \begin{array}{l}\text { 瀉血後 } \\
\text { 日數 }\end{array}$} & \multirow{2}{*}{$\begin{array}{l}\text { 告血 } \\
\text { 球數 } \\
\text { (萬) }\end{array}$} & \multirow{2}{*}{$\begin{array}{l}\text { 血色 } \\
\text { 素量 }\end{array}$} & \multirow{2}{*}{ 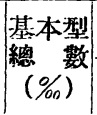 } & \multicolumn{2}{|c|}{ 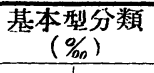 } & \multirow{2}{*}{$\frac{A}{A+B} \times 100$} & \multirow{2}{*}{$\frac{B}{A+B} \times 100$} \\
\hline & & & & & A & B & & \\
\hline $\begin{array}{l}3 / \mathrm{II} \\
5 / 11\end{array}$ & 演血前 & 600 & 91 & 6.6 & 1.6 & 5.0 & 24.2 & 75.8 \\
\hline $7 / / 1$ & 1 & 322 & 50 & 28.3 & 11.7 & 16.6 & 41.4 & 58.6 \\
\hline $9 / / /$ & 3 & 423 & 58 & 63.3 & 33.0 & 30.7 & 52.0 & 48.0 \\
\hline $11 / /$ & 5 & 450 & 65 & 52.7 & 16.3 & 36.4 & 31.0 & 69.0 \\
\hline $13 / " /$ & 7 & 497. & 70 & 36.3 & 5.8 & 31.0 & 14.6 & 85.4 \\
\hline $15 / / /$ & 9 & 518 & 73 & 36.0 & 4.0 & 32.0 & 11.1 & 88.9 \\
\hline $17 / / /$ & 11 & 553 & 85 & 13.0 & 0 & 13.0 & 0 & 100.0 \\
\hline $19 / / /$ & 13 & 556 & 77 & 20.3 & 2.3 & 18.0 & 11.3 & 88.7 \\
\hline $21 / / "$ & 15 & 565 & 79 & 17.6 & 3.3 & 14.3 & 18.7 & 81.3 \\
\hline $23 / 1 /$ & 17 & 556 & 77 & 23.3 & 3.3 & 20.0 & 14.2 & 85.8 \\
\hline $25 / \|$ & 19 & 605 & 84 & 10.0 & 1.0 & 9.0 & 10.0 & 90.0 \\
\hline $27 / / 1$ & 21 & 587 & 91 & 7.7 & 0 & 7.7 & 0 & 100.0 \\
\hline
\end{tabular}

體重 2950 瓦 $6 / \mathrm{Ir} ， 58$ c.c. 瀉血。

茀九表 $\mathrm{Nr} .26$

\begin{tabular}{|c|c|c|c|c|c|c|c|c|}
\hline \multirow{2}{*}{ 月 日 } & \multirow{2}{*}{$\left|\begin{array}{l}\text { 墛血後 } \\
\text { 日數 }\end{array}\right|$} & \multirow{2}{*}{$\begin{array}{l}\text { 赤血 } \\
\text { 球數 } \\
(\text { 萬) }\end{array}$} & \multirow{2}{*}{$\begin{array}{l}\text { 血色 } \\
\text { 素量 }\end{array}$} & \multirow{2}{*}{\begin{tabular}{|c|} 
基本型 \\
總 \\
$(\%)$ \\
$\left(\frac{1}{b^{2}}\right.$ \\
$(\%)$
\end{tabular}} & \multicolumn{2}{|c|}{$\begin{array}{c}\begin{array}{c}\text { 基本型分類 } \\
(\%)\end{array} \\
\end{array}$} & \multirow{2}{*}{$\frac{A}{A+B} \times 100$} & \multirow{2}{*}{$\frac{B}{A+B} \times 100$} \\
\hline & & & & & $A$ & B & & \\
\hline $\begin{array}{l}6 / \mathrm{II} \\
8 / 11 \\
\end{array}$ & 滨血前 & 667.5 & 103 & 10.7 & 3.0 & 7.7 & 28.1 & 71.9 \\
\hline $12 / "$ & 1 & 393 & 61 & 17.3 & 7.6 & 9.7 & 43.9 & 56.1 \\
\hline $14 / "$ & 3 & 398 & 66 & 115.3 & 57.3 & 58.0 & 49.7 & 50.3 \\
\hline $16 / \|$ & 5 & 496 & 75 & 158.0 & 79.0 & 79.0 & 50.0 & 50.0 \\
\hline $18 / \|$ & 7 & 514 & 85 & 68.3 & 15.0 & 53.3 & 21.8 & 78.2 \\
\hline $20 / 1 /$ & 9 & 585 & 93 & 50.3 & 8.6 & 41.7 & 16.7 & 83.3 \\
\hline $22 / \|$ & 11 & 598 & 92 & 29.7 & 1.0 & 28.7 & 3.4 & 96.6 \\
\hline $24 / "$ & 13 & 601 & 96 & 30.0 & 3.3 & 26.7 & 11.0 & 89.0 \\
\hline $26 / / 1$ & 15 & 616 & 101 & 25.3 & 3.7 & 21.6 & 14.6 & 85.4 \\
\hline $28 / \|$ & 17 & 690 & 103 & 22.6 & 4.3 & 18.3 & 19.0 & 81.0 \\
\hline
\end{tabular}




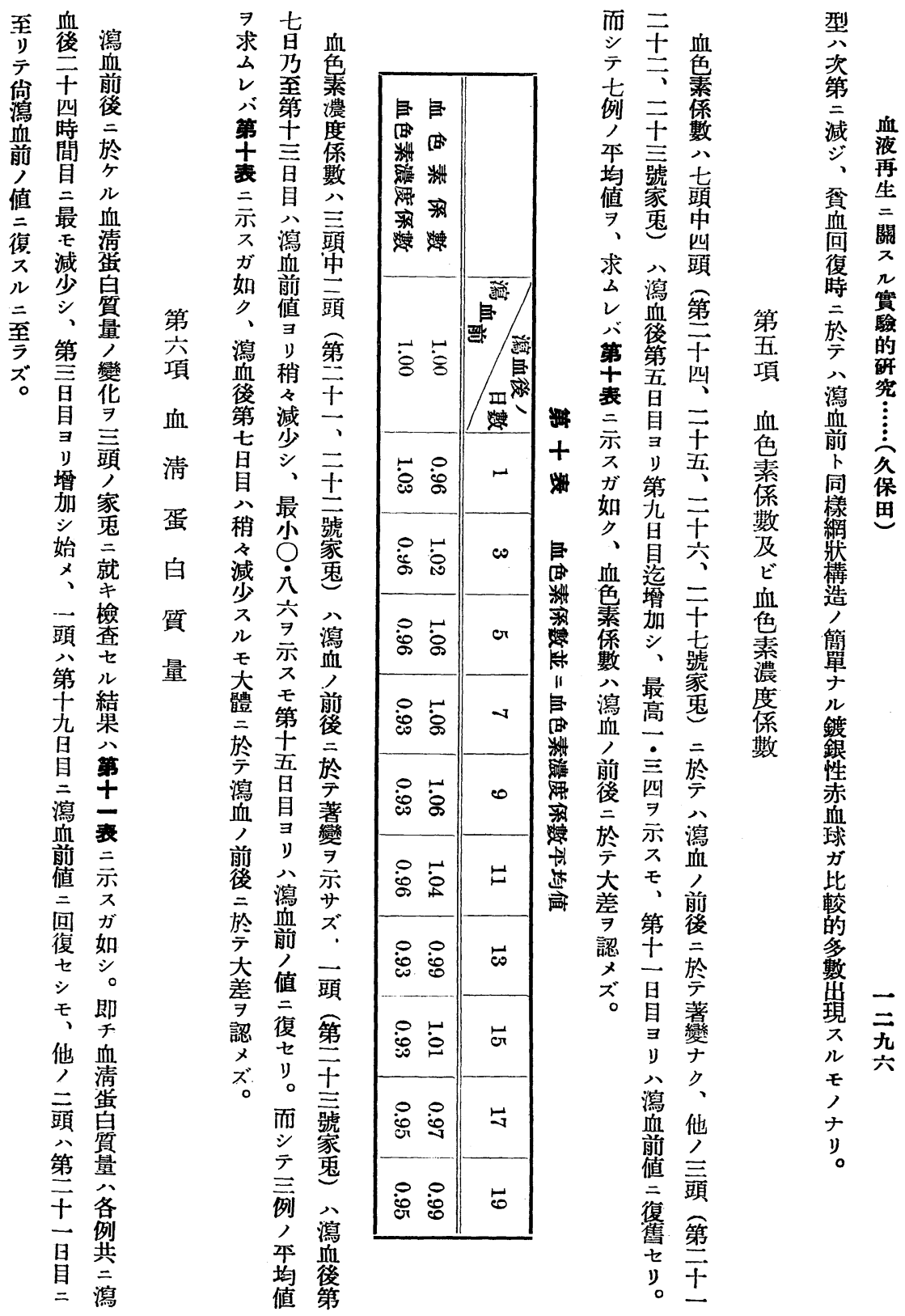




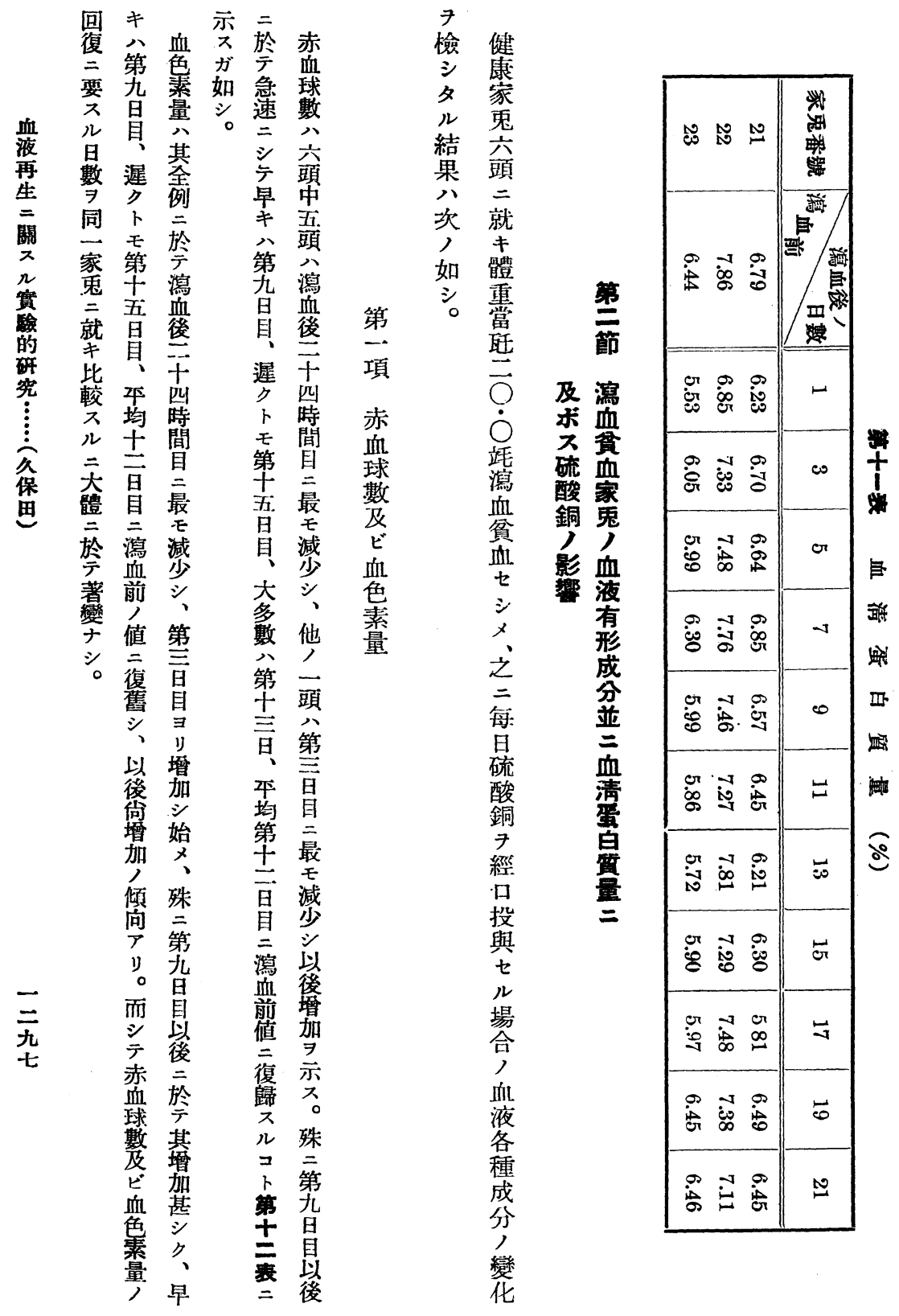


第 + 二表

\begin{tabular}{|c|c|c|c|c|c|c|c|c|c|c|}
\hline \multirow{2}{*}{$\begin{array}{l}\text { 家 } \\
\text { 鬼 } \\
\text { 番 } \\
\text { 踋 }\end{array}$} & \multirow{2}{*}{$\begin{array}{l}\text { 體 } \\
\text { 重 } \\
\text { (正) }\end{array}$} & \multirow{2}{*}{ 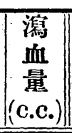 } & \multicolumn{2}{|c|}{ 潟 血 前 } & \multicolumn{2}{|c|}{ 㴼血後第一日目 } & \multicolumn{2}{|c|}{ 回 復時 } & \multicolumn{2}{|c|}{$\begin{array}{l}\text { 回復二要 } \\
\text { セシ日數 }\end{array}$} \\
\hline & & & $\begin{array}{c}\text { 赤血球數 } \\
(\text { 萬) }\end{array}$ & $\begin{array}{c}\text { 血色素 } \\
(\%) \\
\end{array}$ & $\begin{array}{c}\text { 赤血球數 } \\
\end{array}$ & $\begin{array}{c}\text { 血色素量 } \\
\end{array}$ & 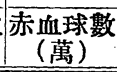 & \begin{tabular}{|c} 
血色素量 \\
\end{tabular} & 赤血珠 & 血色素 \\
\hline 28 & $2760 \mid$ & 56 & 599 & 91 & 317 & 50 & 619 & 91 & 9 & 13 \\
\hline 29 & $2560 \mid$ & 51 & 672 & 101 & 385 & 54 & 726 & 101 & 13 & 13 \\
\hline 30 & $2900 \mid$ & 58 & 638 & 103 & 362 & 59 & 640 & 103 & 15 & 15 \\
\hline 31 & 2730 & 55 & 644.5 & 92 & 466 & 61 & 695 & 92 & 11 & 11 \\
\hline 32 & 2730 & 55 & 641 & 96 & 456 & 66 & 642 & 98 & 13 & 11 \\
\hline 33 & 2700 & 54 & 728 & 94 & 420 & 66 & 736 & 94 & 13 & 9 \\
\hline $\begin{array}{l}\text { 事 } \\
\text { 均 }\end{array}$ & 2730 & 54.8 & 653.8 & 96.2 & 401.0 & 59.3 & 676.3 & 96.5 & 12 & 12 \\
\hline
\end{tabular}

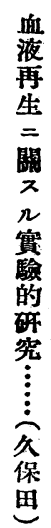

第十三表 赤血球容積 （\%)

\begin{tabular}{|c|c|c|c|c|}
\hline 家鬼番號 & 瀉血前 & 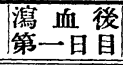 & 回復時 & 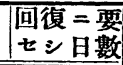 \\
\hline 31 & 39.4 & 28.0 & 39.5 & 11 \\
\hline 32 & 39.0 & 25.3 & 39.8 & 11 \\
\hline 33 & 41.5 & 24.7 & 40.0 & 11 \\
\hline 平均 & 40.0 & 26.0 & 39.8 & 11 \\
\hline
\end{tabular}

第十四表 赤血球一個 /本均容栍 $\left(\mu^{3}\right)$

\begin{tabular}{|c|c|c|c|c|c|c|}
\hline 家鬼番號 & 潟血前 & 舅血大後 & 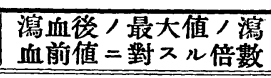 & \begin{tabular}{|l|} 
潟血後最大值 \\
示天日數 \\
\end{tabular} & 回復時 & 回復時 \\
\hline 31 & 61 & 73 & 1.20 & 3 & 54 & 5 \\
\hline 32 & 61 & 69 & 1.13 & 3 & 61 & 7 \\
\hline 33 & 57 & 62 & 1.09 & 11 & 55 & 13 \\
\hline 本均 & 59.7 & 68.0 & 1.14 & 6 & 56.7 & 8 \\
\hline
\end{tabular}




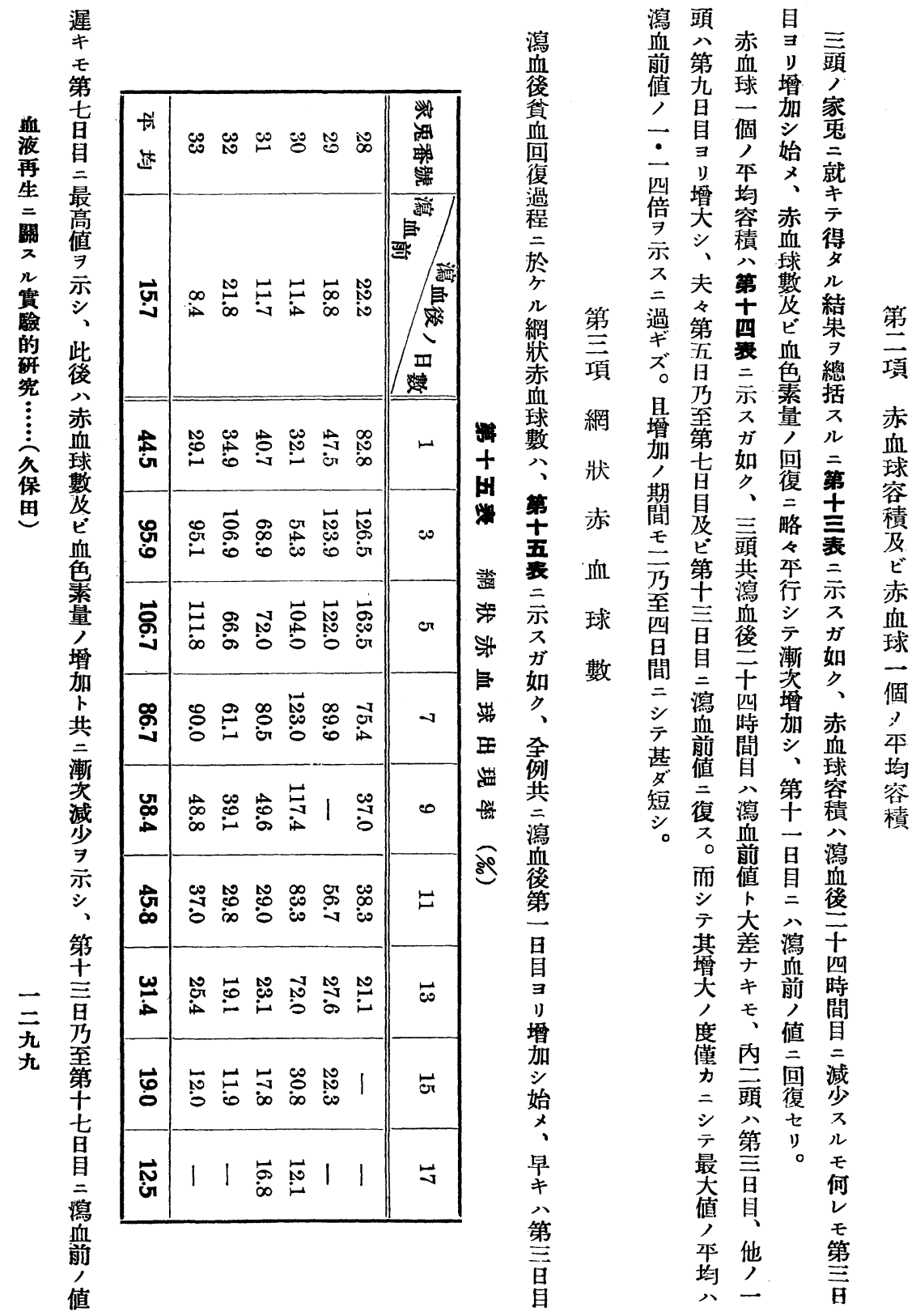




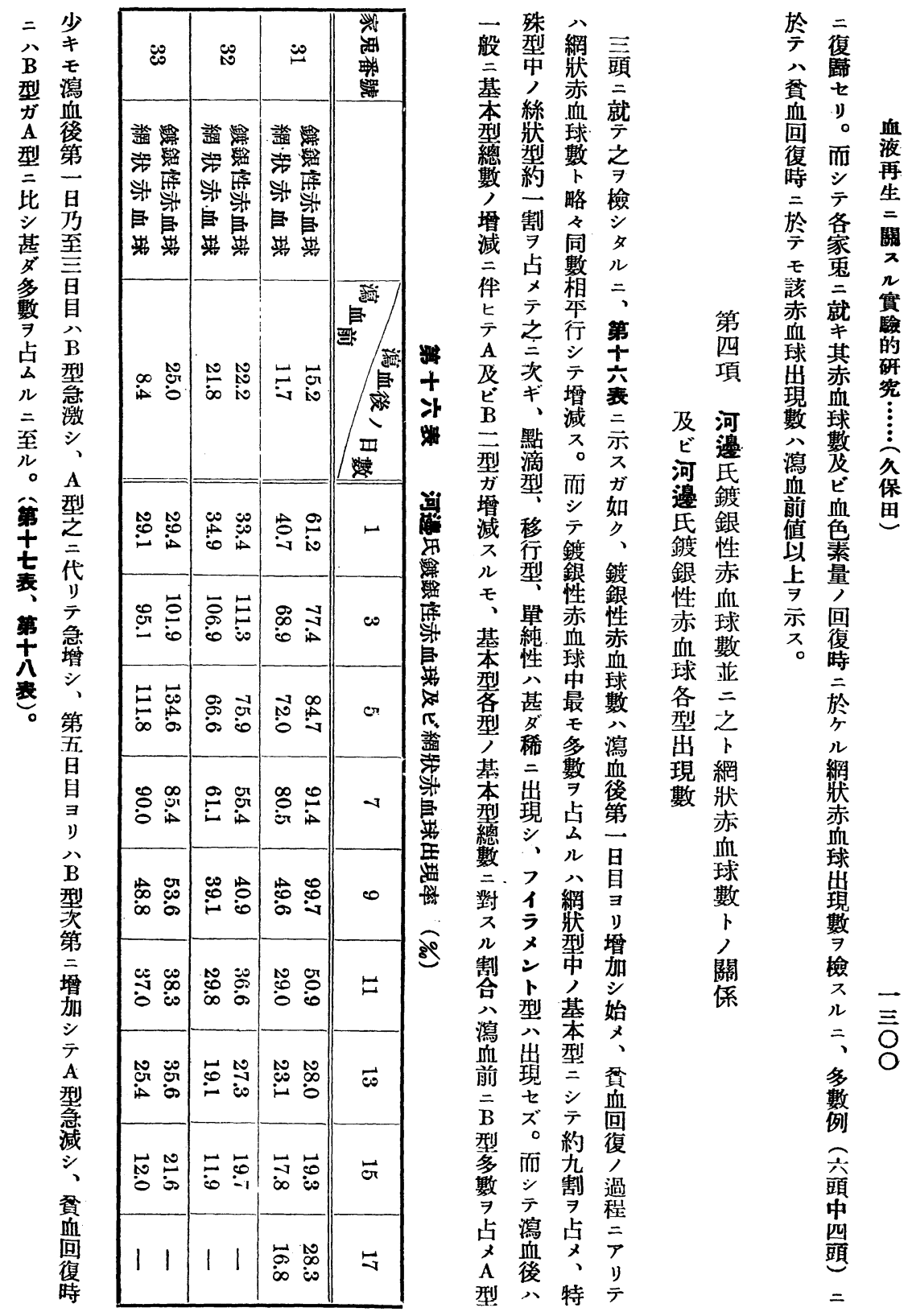


第十七表 Nr. 32 .

\begin{tabular}{|c|c|c|c|c|c|c|c|c|}
\hline \multirow{2}{*}{ 月．日 } & \multirow{2}{*}{$\mid \begin{array}{l}\text { 瀉血後 } \\
\text { ，日數 }\end{array}$} & \multirow{2}{*}{$\begin{array}{l}\text { 赤血 } \\
\text { 球數 } \\
\text { (萬) }\end{array}$} & \multirow{2}{*}{$\begin{array}{l}\text { 血色 } \\
\text { 素量 }\end{array}$} & \multirow{2}{*}{$\begin{array}{c}\text { 基本型 } \\
\text { 總 } \\
(\%)\end{array}$} & \multicolumn{2}{|c|}{$\begin{array}{c}\text { 基本型分類 } \\
(\%)(\%)\end{array}$} & \multirow{2}{*}{$\frac{A}{A+B} \times 100$} & \multirow{2}{*}{$\frac{B}{A+B} \times 100$} \\
\hline & & & & & A & B & & \\
\hline $\begin{array}{l}15 / \mathrm{III} \\
16 / \|\end{array}$ & 瀉血前 & 641 & 96 & 19.9 & 5.6 & 14.3 & 28.1 & 71.9 \\
\hline $20 / 1 "$ & 1 & 456 & 66 & 30.0 & 13.0 & 17.0 & 43.3 & 56.7 \\
\hline $22 / 1 /$ & 3 & 485 & 77 & 103.6 & 43.6 & 60.0 & 42.1 & 57.9 \\
\hline $24 / / /$ & 5 & 512 & 81 & 76.0 & 18.0 & 58.0 & 22.8 & 76.2 \\
\hline $26 / 1 /$ & 7 & 610 & 88 & 49.7 & 11.0 & 38.7 & 22.1 & 77.9 \\
\hline $28 / 1 /$ & 9 & 627 & 95 & 35.3 & 3.3 & 32.0 & 9.2 & 90.8 \\
\hline $30 / / /$ & 11 & 634 & 98 & 34.6 & 8.3 & 26.3 & 24.2 & 76.0 \\
\hline $1 / \mathrm{IV}$ & 13 & 642 & 98 & 24.3 & 4.6 & 19.7 & 19.0 & 81.0 \\
\hline $3 / 11$ & 15 & 731 & 101 & 18.4 & 1.7 & 16.7 & 9.2 & 90.8 \\
\hline 體 & & & & & 血。 & & & \\
\hline
\end{tabular}

第十八数 Nr. 33

\begin{tabular}{|c|c|c|c|c|c|c|c|c|}
\hline \multirow{2}{*}{ 月 日 } & \multirow{2}{*}{ 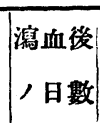 } & \multirow{2}{*}{$\begin{array}{l}\text { 赤血 } \\
\text { 球數 } \\
\text { (萬) }\end{array}$} & \multirow{2}{*}{$\begin{array}{l}\text { 血色 } \\
\text { 素量 }\end{array}$} & \multirow{2}{*}{$\begin{array}{l}\text { 基本型 } \\
\text { 總 } \\
(\% \text { 數 }\end{array}$} & \multicolumn{2}{|c|}{$\begin{array}{c}\text { 基本型分類 } \\
(\%) （ \%)\end{array}$} & \multirow{2}{*}{$\frac{A}{A+B} \times 100$} & \multirow{2}{*}{$\frac{B}{A+B} \times 100$} \\
\hline & & & & & A & B & & \\
\hline $\begin{array}{l}15 / \text { IIII } \\
16 / \|\end{array}$ & 䳆血前 & 728 & 94 & 22.7 & 4.0 & 18.7 & 17.3 & 82.7 \\
\hline $20 / 11$ & 1 & 420 & 66 & 28.7 & 9.3 & 19.4 & 32.2 & 67.8 \\
\hline $22 / 11$ & 3 & 497 & 77 & 95.6 & 51.6 & 44.0 & 54.0 & 46.0 \\
\hline $24 / \|$ & 5 & 586 & 82 & 126.0 & 57.3 & 68.7 & 45.5 & 54.5 \\
\hline $26 / 11$ & 7 & 617 & 88 & 76.7 & 25.0 & 51.7 & 32.7 & 67.3 \\
\hline $28 / "$ & 9 & 619 & 94 & 52.6 & 16.0 & 36.6 & 30.4 & 69.6 \\
\hline $30 / 11$ & 11 & 647 & 94 & 36.0 & 4.3 & 31.7 & 12.0 & 88.0 \\
\hline $1 / \mathrm{IV}$ & 13 & 736 & 99 & 34.3 & 6.0 & 28.3 & 17.3 & 82.7 \\
\hline $3 / 11$ & 15 & 733 & 96 & 19.6 & 3.3 & 16.3 & 16.9 & 83.1 \\
\hline
\end{tabular}




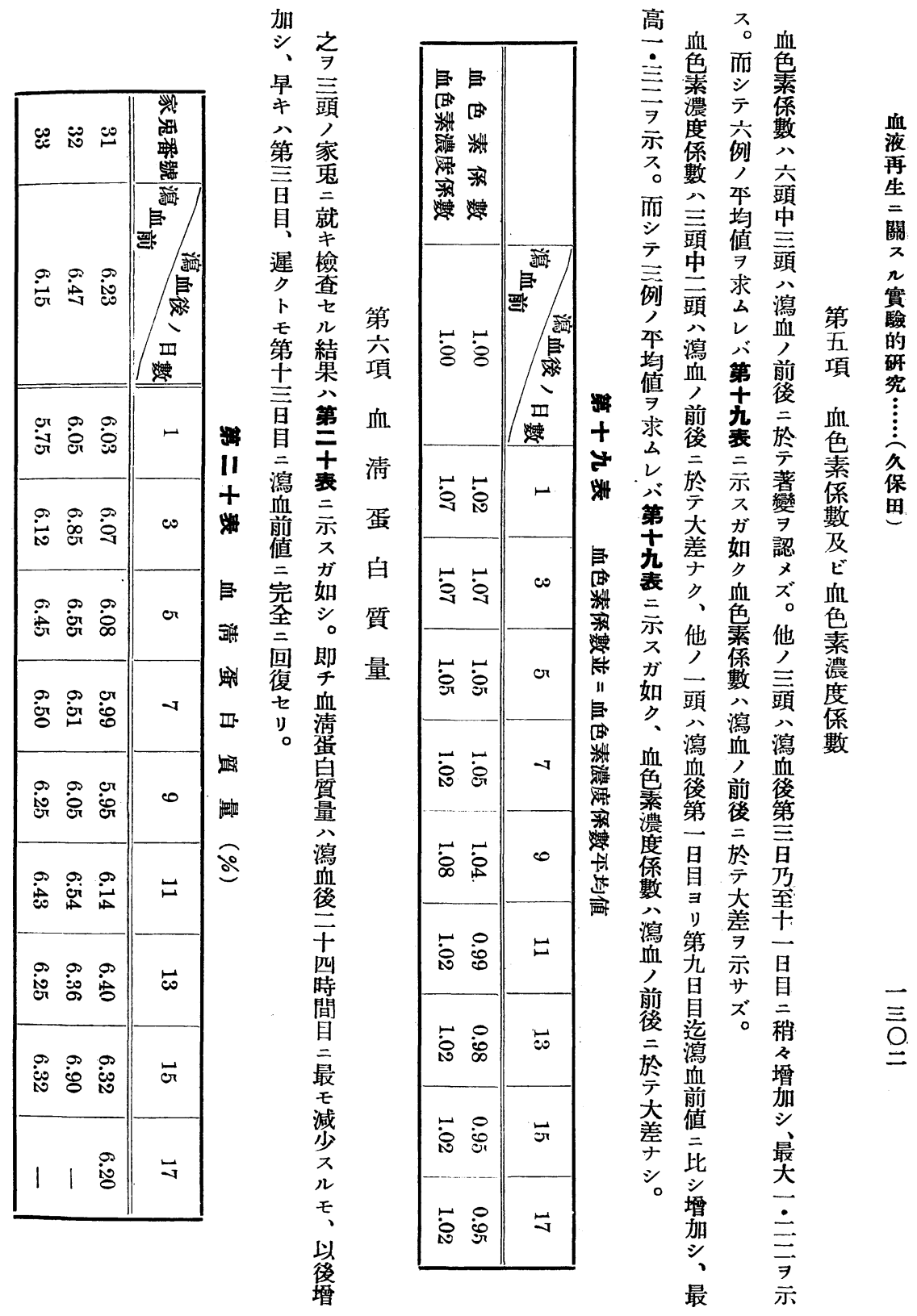


投回銅 日

與 赤 復 八數 血 即 家血二赤八色于

兔 球 無 血 相 素赤 血八容 效 球 等 量 血 液第積ナ生方, 球 再十八リ成。回數 生一瀉卜 日血, 促于 $=$ 二 關目後成進 還 要 血 几二三績 實瀉十トル鐵ル素 驗血四八モ亚日量 的 前 時 一 血二數, 研 值 間 致色硫 7 回 究二目七素酸比復 $\vdots$ 回二ズ 合銅較速 緮最。成八度

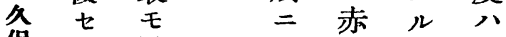
保り減血二銅 田。少僅球、投 而 シ力數 鐵 與 シ 二 及或家 テ 第 作 ビ 八兔 赤 三 用 血 銅 V 血白 ス色投鐵 球目 ル 素 與 投 一 $\exists$ 量 $>$ 與 個りノ有家 增 ナ回無兔 平加り復二V 均 シ 容 始 積 、田芯 ズ主 鐵 對 总程血 照 度 球 示 銅 亚

一投 與 鐵

三人 投

焉 舆

二鬼

抬了

亏 第

ス。

何自

$\sim=$

㶅 銅

成 淮 ビ 叉

績 的 血 同

亚 二 色 -..

二作 素 家

浮用, 兔

田 ス回二

ガル 復 就

硫モニテ

酸, 要 其

銅 二 ス 赤

八 シ ル 血

貧亏、尔球

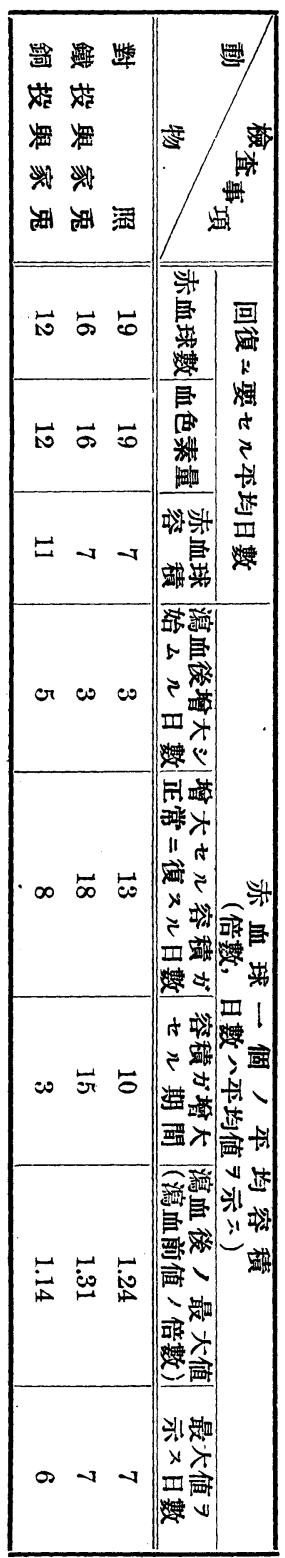

=

ス カ 得

如 夕

シ 赤

血

數

血

第

總

赤

血 括

球

容

並

並 =

赤 考

血

察

個

平

均

谷

積

猎武

ス

ル

成

績

尹

括

表

洁

ス

ᄂ

第 
第二十二患 渴血後網狀赤血球數 最高值

\begin{tabular}{|c|c|c|c|c|c|}
\hline \multicolumn{2}{|c|}{ 㴼血後ノ日數 } & 3 & 5 & 7 & 計 \\
\hline \multirow{2}{*}{$\begin{array}{l}\text { 銅 } \\
\text { 投 } \\
\text { 與 }\end{array}$} & $\begin{array}{l}\text { 頭数 } \\
\end{array}$ & 2 & 2 & 2 & 6 \\
\hline & $\%$ & 33.3 & 33.3 & 3.33 & 100.0 \\
\hline $\begin{array}{l}\text { 鐵 } \\
\text { 投 } \\
\text { 與 }\end{array}$ & $\begin{array}{l}\text { 頭 } \\
\text { 數 }\end{array}$ & 2 & 4 & 1 & 7 \\
\hline 與 鬼 & $\%$ & 28.6 & 57.1 & 14.3 & 100.0 \\
\hline 對 & $\begin{array}{l}\text { 頭 } \\
\text { 數 }\end{array}$ & 4 & 6 & 0 & 10 \\
\hline 照 & $\%$ & 40.0 & 60.0 & 0 & 100.0 \\
\hline
\end{tabular}

網 兔 日 示三時

狀 亚 數

赤二小

血 對 對

球 照 照

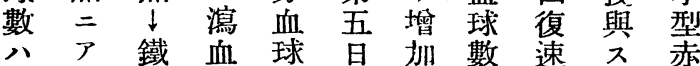

多り投前數目シ人ノカ血

クテ與ノ及鐵、瀉ナ時球

八 家值 ビ或第血

場 赤兔二血八三後卜還多貧

合血銅回色銅士貝主元數血

既 球 投 復 素投三血張鐵出人

二數 與 七 量 與 表 回 七投現二

鼬亚家り家三復 シ 與 7 於

血二鬼。回鬼示過

前血) 即復二

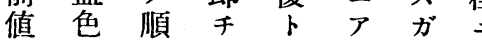

二素二瀉共り如於

復 量 鼠血二テク

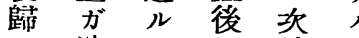

シ瀉、網 第

對 消

ル前向赤減方家 7 、血村赤

モ值 $ア$ 血少至兔見ル球山血

、三リ球 シ 第二ル 事容二球大

銅回。數 第七七

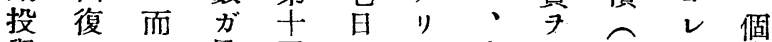

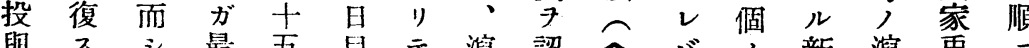

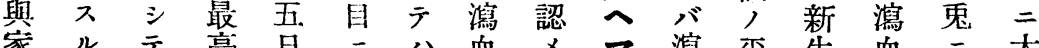

兔時 鐵 值 吅 最瀉 後ザ

二期投 至高血云リク家容血血り シ

於
多村 對 換 血

數 山 照 言 後

現瀉リ $リ$ 吅

尹 血 モ バ

家 平 鐵 來

均投 ス 再

容 與 モ 生

小兔 瀉 關

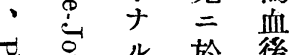

$n$

實

的

研

究

出 $\exists$ 及

ஸे

保

田

後 積

7 期 增

間大

互ル

即責 八

司岙

儿 與

峦 鬼

球 V

出 剧

現 V

見 投

四
○容間 


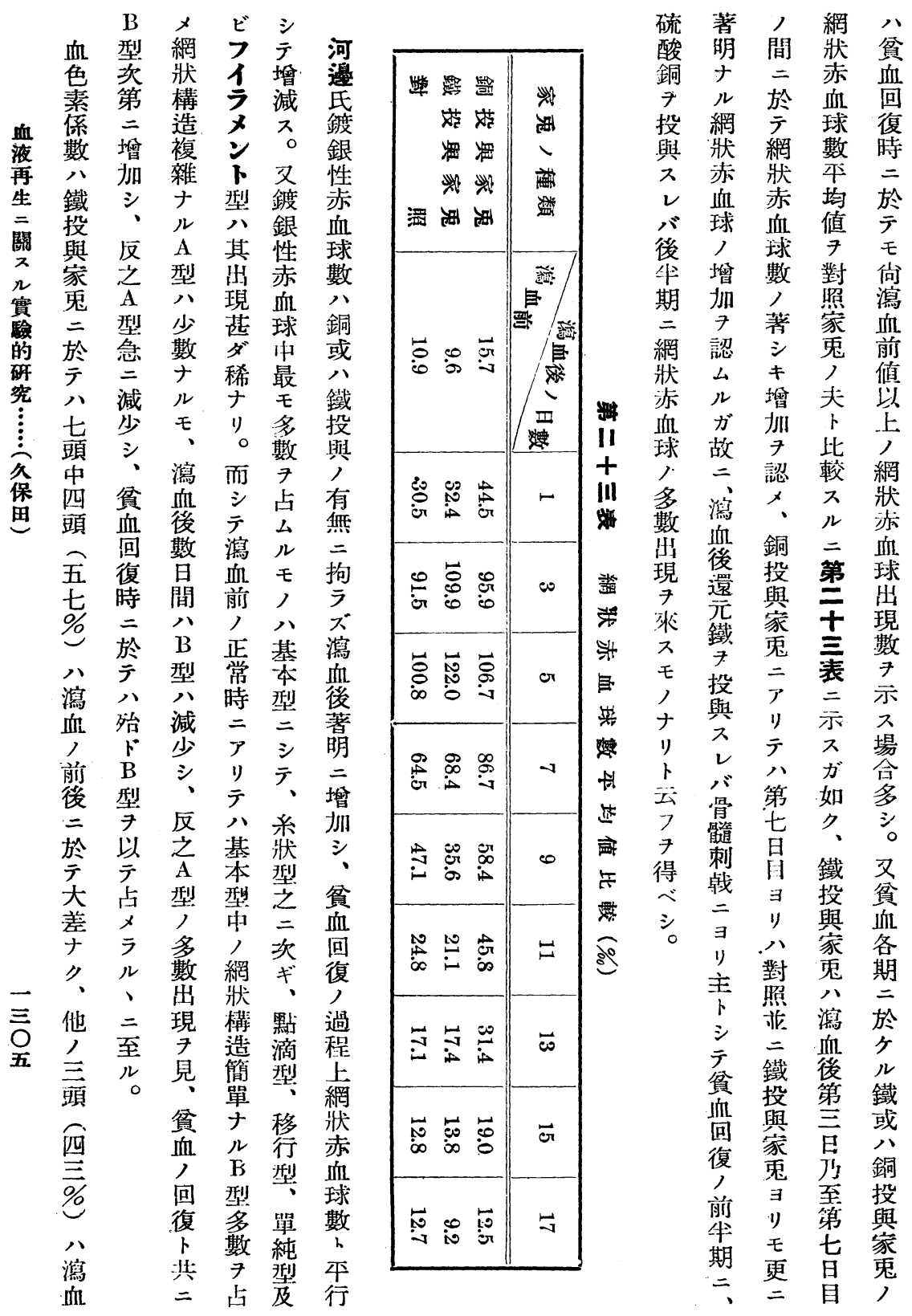


示 ガ 加 㮐

ス如六 シ 血

ク \% 減色

對八照七濃

照增 二 リ度

卜加 $ア \circ$ 係

鐵 リ 銅 數

投示厅投心

與 ス八與 鐵

家。七家 投

鬼 而 頭 鬼 與

二 シ 中 二 家

於 テ三ア鬼

テ 鐵 頭 リ二

八或 テ

大八四八!

差銅 七 三 テ

ナ投 \% 頭

キ與

モ芜

銅兔瀉頭 中

投 群 血 亲 三

與及ノ六䫒

家 ビ前 對 兵

兔 對 後 \% 六

二照 群

リ群 於 小

テ血著血

》色變, 竄

貧素 ナ 前血

血濃り後前

旬度、二後

復係三於二

人數 頭 テ 於

過ノ大

程本四差大

二均七大差

於值 $\%$ ク宁

テ 7 -

前求 八頭 一

二 么 瀉 $气$ 頭

者レ 血 三さ

$\begin{array}{llll}\text { モ } & \text { 墄 } & \% & \text { 三 } \\ \text { 稍 五 } & \text { シ } & \text { 少 } & \end{array}$

名他瀉，

增 二八血演

加示 - 後 血

万頭增 後

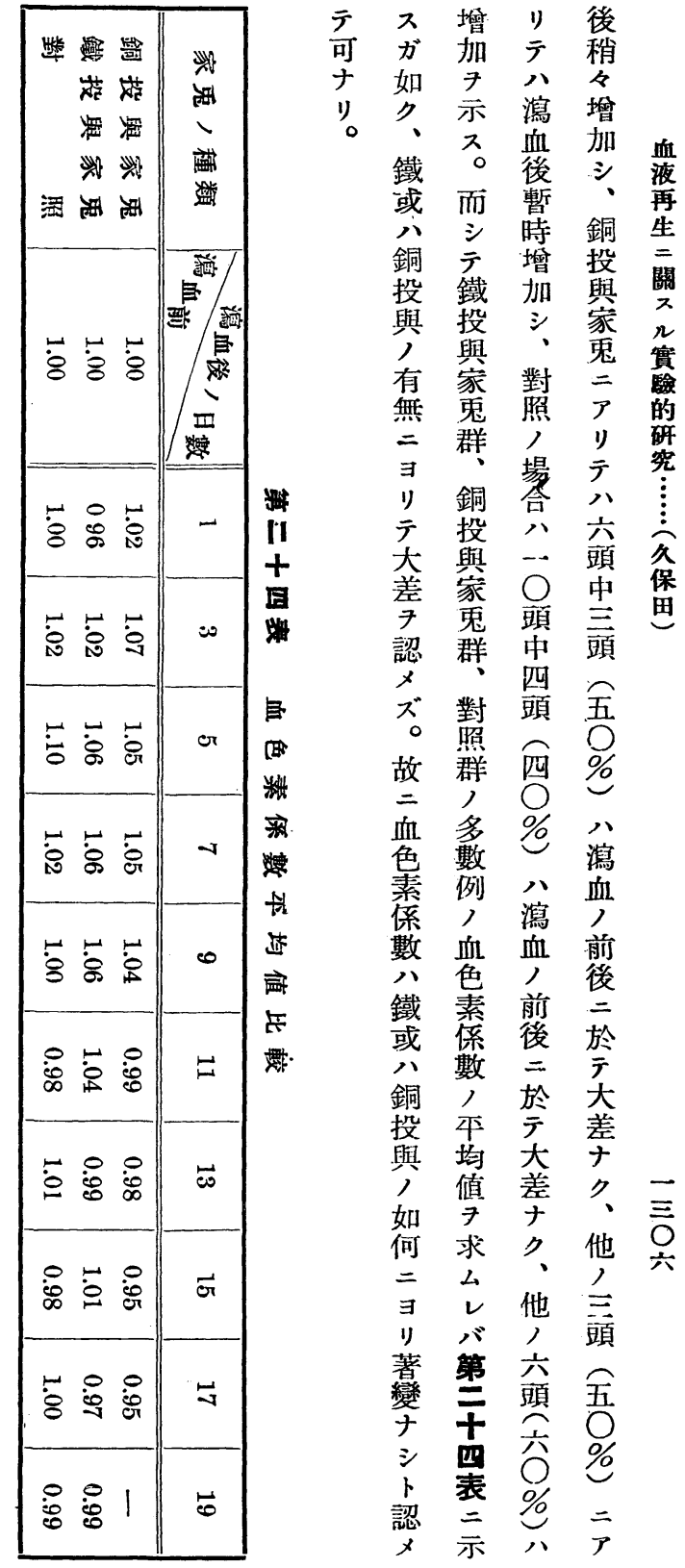




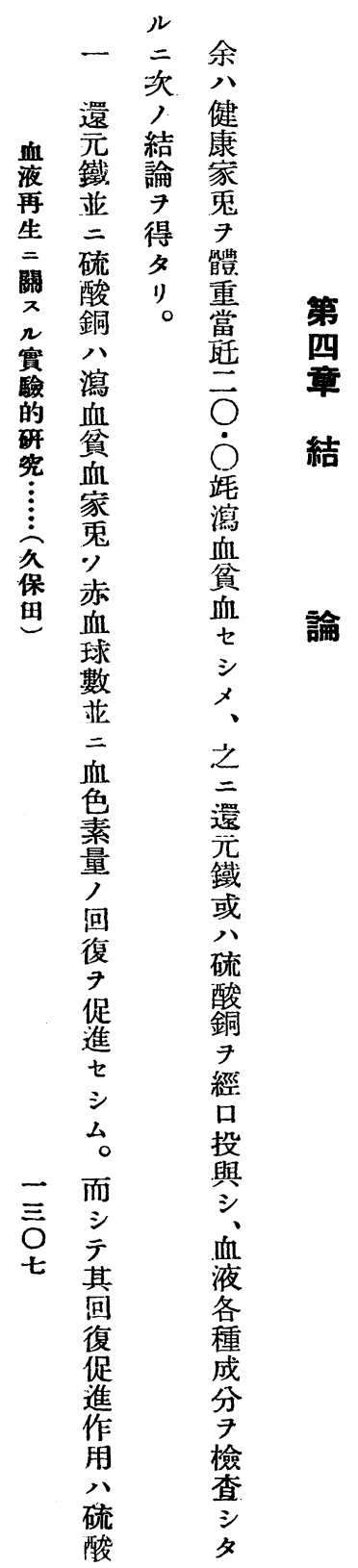

リ於 八, 後

テ 其 回 基即

血儿全復十千

清 血 例占四

蛋清二共時 八

白蛋於二間田

質 白テ

量質、部二

量早八最舟

增ノ漆飞久

第量回八血減保

四 復 第 前 少 等

車見荠值三,

結江奛自復瀉入

モ 、歸 血

余促遐 三 前 如

ガ進ク・值キ

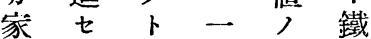

鬼 シモ部約 投

二厶第 八九 與

於ル土瀉 0 、後

多

璸 自值ナ色

驗 見 $=$ = 素

二夕、全モ係

於儿瀉”、數

$\bar{テ} 八$ 血八以,

八新前回後上

之知傎復漸 昇

尹見二七次八

認ナ完ザ增之

ムり全ル加

占三モ三認

事入回, 、

子。復乃鐵 ザ

得反 $t$ 》投》

ザ之り。テ與ま

り田即定家嵬

吉思即定笴血

硫 ズ 丵

舟 酸 。對 白

久 銅銅照 質

保 八投二量

瀉興 $ア$ 公

鐵 血家り何

投貧鬼うと

與 血 $=八 乇$

二時 於貧瀉

$\exists=$ 衁 血

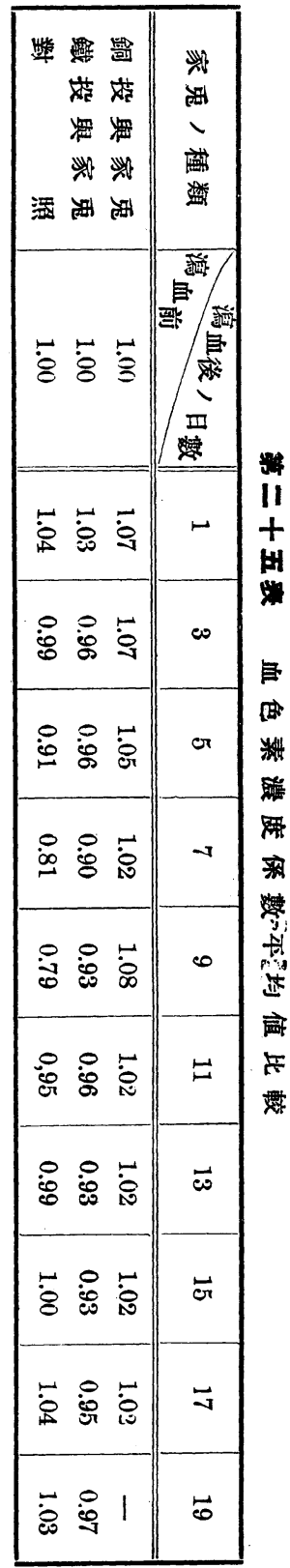




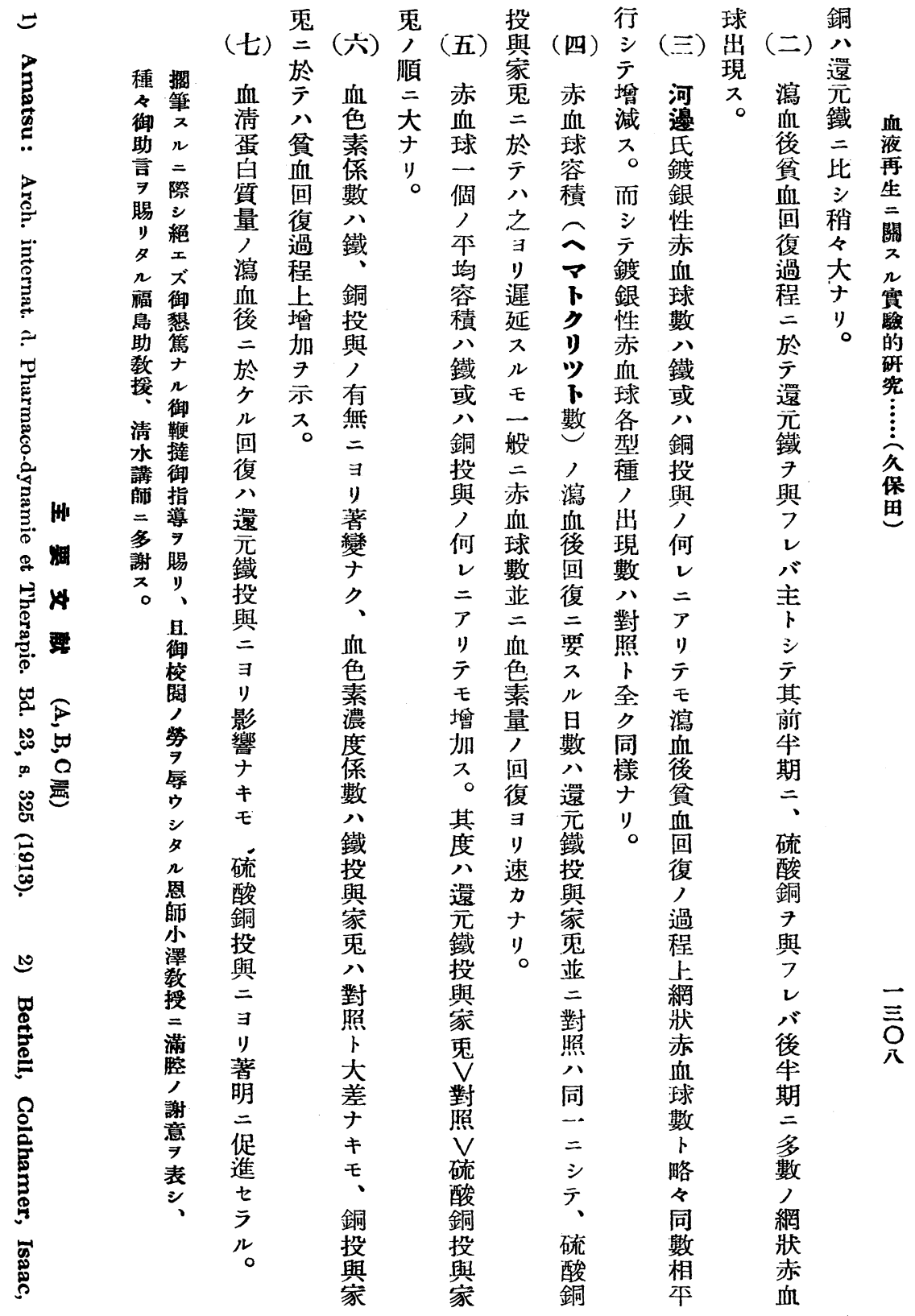




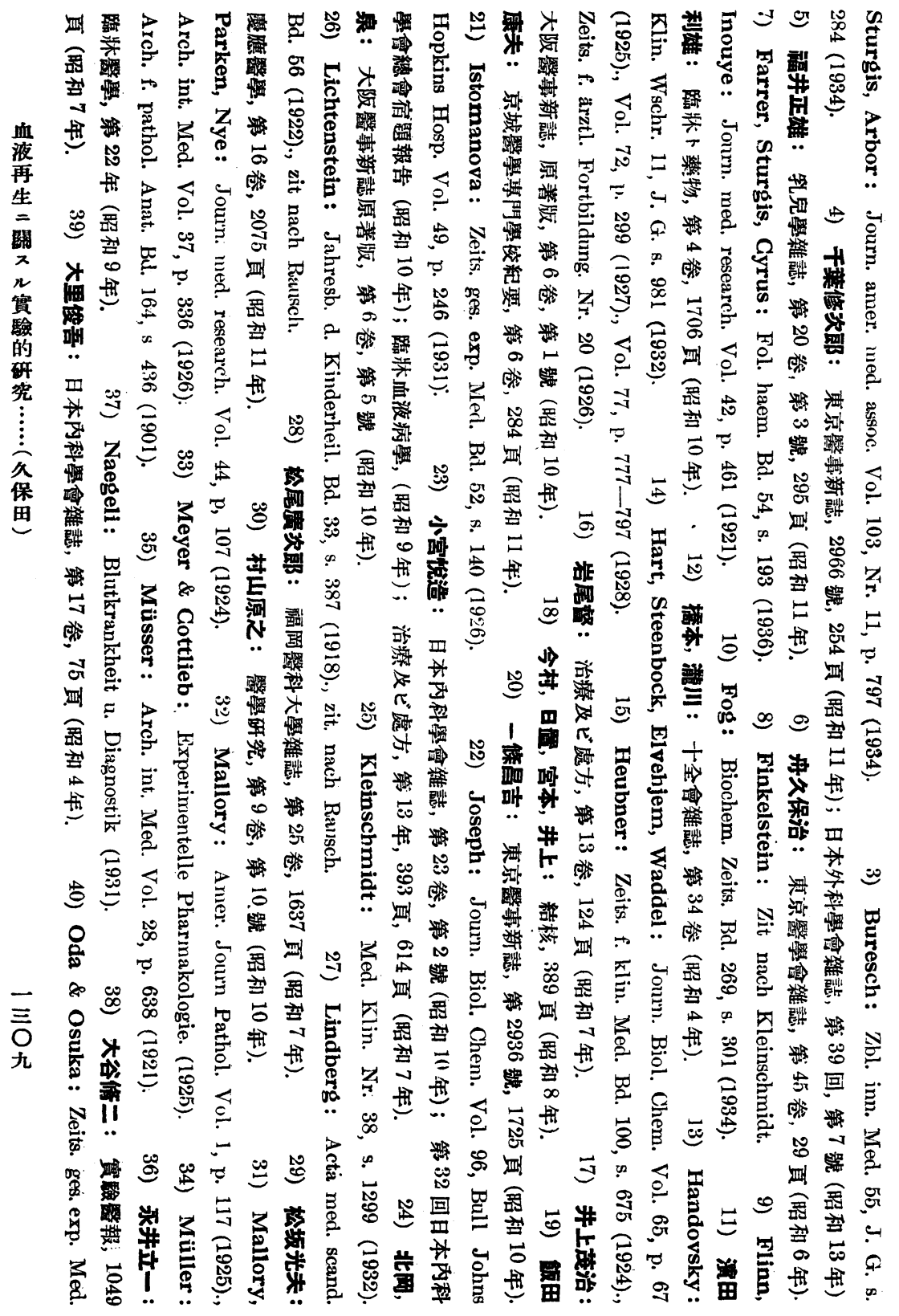




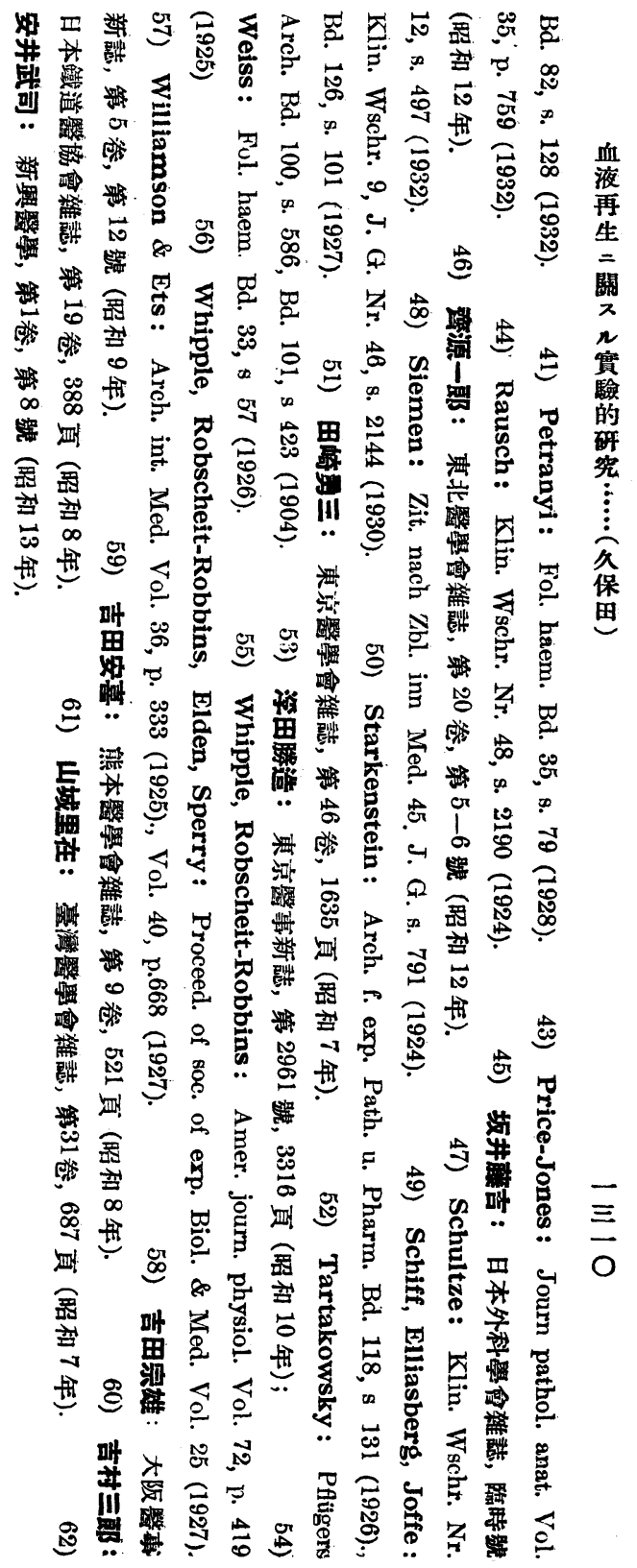


vertreten war. Im normalen Zustand überwog der Typus B (mit einfachem Netzwerk versehner Grundtypus) den Typus A (mit kompliziertem Netzwerk versehner Grundtypus). Einige Tage nach dem Aderlass zeigte Typus A deutliche Zunahme, Typus B dagegen Verminderung. Darauf aber nahm mit den Tagen der Typus A shnell ab und vermehrte sich der Typus B stark. Nach abgeschlossener Blutregeneration war das Verhältnis zwischen Typus A und B $^{-}$wie vor dem Aderlass.

4) Die Hämatokritzahl (39.1\%) hatte am nächsten Tage nach dem Aderlass um ca. 1/3 ihres Anfangswertes abgenommen und erreichte meist am 7. 'Tage nach dem Aderlass ihren ursprünglichen Wert wieder.

5) Das durchschnittliche Erythrozytenvolumen (65.0 $\left.\mu^{3}\right)$ vergrösserte sich während einiger Tage nach dem Aderlass. Aus der Beobachtung des Eiweissgehaltes des Serums in Verlaufe der Blutregeneration ging hervor, dass diese Vergrösserung nicht mit Hydrämie, sondern mit dem Auftreten der voluminösen neugebildeten Erythrozyten zusammenhing.

6) Der Färbeindex veränderte sich nach dem Aderlass nicht deutlich. Der Saturationsindex jedoch zeigte in der Zeit vom 7.-9, Tage nach dem Aderlass geringe Abnahme.

7) Der Eiweissgehalt des Serums $(6.48 \%)$ nahm während der ersten 24 Stunden nach dem Aderlass nur um 1/10 des Anfangswertes $a b$ und näherte sich mit der Regeneration der Erythrozyten und des Hämoglobins seinem Aufangswerte.

(Autoreferat)

\title{
Experimentelle Untersuchungen über die Blutregeneration II. Mitteilung.
}

\author{
Von \\ Dr. T. Kubota.
}

(Aus der 2. Med. Klinik der Kaiserl. Universität zu Osaka in Japan. 


\section{Direktor : Prof. Dr. S. Kozawa.)}

Der Verfasser untersuchte über den Einfluss des Eisens oder des Kupfers auf das erythrozytäre Blntbild und den Eiweissgehalt des Blutserums bei Kaninchen nach dem Aderlass. Es wurde nach dem Aderlass täglich 1 mal per os $0.5 \mathrm{~g}$ Ferrum reductum oder 1.0 c.c. $0.5 \%$ iger wässriger Kupfersulfatlösung pro $3 \mathrm{Kg}$. Körpergewicht gegeben.

Die Resultate waren wie folgt:

1) Ferrum reductum sowie Kupfersulfat beschleunigten beim Kaninchen die Regeneration der Erythrozyten und des Hämoglobins nach dem Aderlass, und zwar das Kupfersulfat etwas stärker als das Ferrum reductum.

2) Die Retikulozytenzahl vermehrte sich durch die Eisengabe auffallend hauptsächlich im Anfangstadium und durch Kupfergabe im Endstadium der Blutregeneration nach dem Aderlass.

3) Die Zahl der Kawabeschen versilberten Erythrozyten ging im Verlaufe der Blutregeneration bei der Eisen- sowie bei der Kupfereinverleibung ganz parallel mit Retikulozytenzahl. Das prozentuale Verhältnis der verschiedenen Typen der versilberten Erythrozyten war fast gleich wie bei den Kontrolltieren.

4) Bei der Eisengabe kehrte die Hämatokritzahl gleichmässig wie beim Kontrolltiere, aber etwas schneller als bei der Kupfergabe auf ihren Anfangswert zurïck.

5) Das durchschnittliche Erythrozytenvolumen vergrösserte sich durch die Eisen- sowie Kupfergabe, und die Daner und der Grad der Vergrösserung waren :

Bei der Eisengabe $>$ beim Kontrolltiere $>$ bei der Kupfergabe.

6) Den Färbeindex im Verlaufe der Blutregeneration beeinflusste weder Eisen noch Kupfer. Der Saturationsindex war bei der Kupfergabe etwas höher als bei der Eisengabe und beim Kontrolltiere.

7) Auf die Rückkehr des Eiweissgehaltes des Blutserums nach dem Aderlass auf seinen Anfangswert übte das Eisen keinen Einfluss aus, durch die Kupfergabe wurde sie jedoch beträchtlich beschleunigt. (Autoreferat) 